\title{
A new species of Parastenocaris from Korea, with a redescription of the closely related $P$. biwae from Japan (Copepoda: Harpacticoida: Parastenocarididae)
}

\author{
Tomislav Karanovic ${ }^{1,2, *}$ and Wonchoel Lee ${ }^{1}$ \\ ${ }^{1}$ Department of Life Science, Hanyang University, 17 Haengdang-dong, Seongdong-gu, Seoul 133-791, Korea \\ ${ }^{2}$ University of Tasmania, Institute for Marine and Antarctic Studies, Cnr Alexander and Grosvenor Sts, Private Bag 129, \\ Hobart, Tasmania 7001, Australia \\ *Correspondent: Tomislav.Karanovic@utas.edu.au
}

\begin{abstract}
Parastenocaris koreana sp. nov. is described based on examination of numerous adult specimens of both sexes from several localities in Korea. Scanning electron micrographs are used to examine intra- and interpopulation variability of micro-characters, in addition to light microscopy. The new species is most closely related to the Japanese $P$. biwae Miura, 1969, which we redescribe based on newly collected material from the Lake Biwa drainage area. The two species differ in size, relative length of the caudal rami, shape of the anal operculum, shape of the genital double somite, relative length of the inner distal process on the female fifth leg, as well as relative length of the apical setae on the second, third, and fourth legs exopods in both sexes. Detailed examinations of three disjunct populations of $P$. koreana reveal also some geographical variation, especially in the surface ornamentation of somites, which may indicate some population structuring or even cryptic speciation. Lack of intraspecific variability in the number and position of sensilla on somites, as well as their potential phylogenetic significance, is a novel discovery. Both species examined here belong to the brevipes group, which we redefine to include 20 species from India (including Sri Lanka), Australia, East Asia, Northern Europe, and North America. A key to species of this group is also provided. In order to test the monophyly of the redefined brevipes group with highly disjunct distribution, as well as relationship between different species, a cladistics analysis is performed based on 39 morphological characters and with help of three outgroup taxa. Six equally parsimonious cladograms are generated, all of which show that the ingroup is well defined by at least three synapomorphies. Reconstructed phylogeny questions the previously suggested hypothesis about the origin of this group in South East Asia, with one Australian species showing the most basal position. We speculate that the present distribution of this group may be a combination of ancient vicariance and subsequent dispersal, with a possible origin in the Gondwanaland, in the rift valley between Australia and India.
\end{abstract}

Keywords: Brevipes group, cladistics, copepod, phylogeny, stygofauna, taxonomy

\section{INTRODUCTION}

Parastenocarididae Chappuis, 1940 is a harpacticoid family highly specialised for life in continental groundwater, and its members are almost exclusively restricted to this habitat (Galassi and De Laurentiis, 2004). They are, however, distributed on all continents except Antarctica and New Zealand (Karanovic, 2004), remarkable considering that stygofauna has a limited active dispersal potential and lacks resting stages that could be dispersed passively (Culver and Pipan, 2009). Because parastenocaridids have no marine relatives or modern pathways between different continents (Boxshall and Jaume, 2000), it has been postulated that they have a Pangean origin
(Karanovic, 2006). In Australia, for example, Karanovic (2004) speculated that they started colonising subterranean waters just after the Permo-Carboniferous glaciation, which spread throughout much of what will subsequently become Gondwana supercontinent and covered the entire Australian plate (Frakes, 1999; Playford, 2003). This makes it likely that present distributions of most parastenocaridids are a result of continental drift (Boxshall and Jaume, 2000), and thus an ideal group to study vicariance models in zoogeography. Unfortunately, no research has been done on their phylogeography so far, except for three genera from Australia (Karanovic and Cooper, 2011a; 2011b). Vicariance has been considered to be a more acceptable hypothesis for explaining zoogeographic connections of freshwater subterranean faunas 
with disjunct distribution patterns (Boxshall and Jaume, 2000; Karanovic, 2004; 2005a; 2006; Karanovic and Ranga Reddy, 2005), whereas dispersal has been regarded traditionally as a better model for explaining recent disjunct distributions of marine and continental surface-water animals (Wilson, 1999; Reid, 2001; Waters and Roy, 2004; Waters and Craw, 2006; Karanovic, 2008). This view was never challenged seriously, although recent debate about New Zealand biogeography showed that we have unjustly underestimated recent long-distance dispersal in favour of ancient vicariance (Sanmartin and Ronquist, 2004; Waters and Craw, 2006). Dispersal cannot be completely rejected even for some subterranean freshwater copepods with disjunct distributions (see Karanovic and Ranga Reddy, 2004), although this can sometimes be a consequence of anthropogenic translocation associated with early shipping activities (Karanovic, 2005b; Karanovic and Krajicek, 2012). Research on families such as Parastenocarididae Chappuis, 1940 is thus very important to help resolve these complex zoogeographical issues.

The family is a monophyletic group within Harpacticoida, being easily distinguished by the sexual dimorphism in the third pair of swimming legs (Corgosinho et al., 2007). Modification of these legs in males into a grasping organ, that allows them to hold females during copulation (Glatzel and Schminke, 1996), is one of the most important synapomorphies of the group (Martínez Arbizu and Moura, 1994), but many other morphological characters make it very easy to instantly recognize its members (Karanovic and Cooper, 2011b). However, a great number of morphological characters are conservative within this family, making generic division a real and long lasting problem (Reid, 1995; Galassi and De Laurentiis, 2004; Karanovic, 2005a; Schminke, 2010), and the family stayed monogeneric for a long time despite a steady accumulation of new species.

Chappuis (1937) divided its only genus Parastenocaris Kessler, 1913 into four groups, which he numbered rather than named, each containing two species. Kunz (1938) added another group. Lang (1948) subdivided the family into eight species groups for 31 of the 40 species known at that time (nine species were either known only as females or were insufficiently described), accepting the group proposed by Kunz (1938), but rearranging three of those proposed by Chappuis (1937) and naming them after the most characteristic species. For diagnosing all these groups all three authors mostly used characters of the male fourth leg endopod. Despite being chiefly based on a single character, Lang's system was widely accepted and was coping rather well with a subsequent steady influx of newly described species from around the world, culminating in the decade between 1963 and 1972 when 75 new species were added (Schminke, 2010). Five new species groups were added subsequently by Noodt (1962;
$1963 ; 1972)$, mostly for the newly discovered and very diverse South American fauna, but it became apparent that this increasingly more complex system of species groups was not a reflection of true phylogenetic relationships, which were not taken into account in descriptions of many newly proposed taxa (species and subspecies).

Jakobi (1969) described one of the Noodt's groups as a new genus, and it was Jakobi (1972) who made the first effort to revise the family by splitting it into 26 different genera, although only assigning to them 98 out of the 155 then known species. This system was strongly criticised by Schminke (1976), and was ignored for a long time by most subsequent taxonomists working on this group, all of them accepting only two of Jakobi's genera (see Por and Hadel, 1986; Dussart and Defaye, 1990; Reid, 1995; Karanovic and Bobic, 1998; Ranga Reddy, 2001; Galassi and De Laurentiis, 2004; Boxshall and Halsey, 2004; Karanovic, 2005a; 2006; Cottarelli et al., 2006; 2007, 2008; Wells, 2007; Ranga Reddy and Defaye, 2007; 2009; Huys, 2009). In a few isolated cases Jakobi's genera were treated as subgenera (see Kiefer, 1976). Jakobi (1972), for example, divided the brevipes group of Lang (1948) into five different genera, which was shown by Reid (1995) to be a group of very closely related species. Reid (1995) even argued that the type species of one new genus proposed by Jakobi (Biwaecaris) is in fact a junior subjective synonym of the type species of Parastenocaris. Nevertheless, new genera were proposed for some unusual new members from South America (Dussart, 1979; Reid, 1994), Europe (Galassi and De Laurentiis, 2004), Africa (Schminke, 2009), Asia (Cottarelli et al., 2010), and Australia (Karanovic and Cooper, 2011b), and two more groups of species were proposed by Berera and Cottarelli (2003) and Galassi and De Laurentiis (2004). Recently, some researchers (Corgosinho and Martínez Arbizu, 2005; Schminke, 2008; Corgosinho et al., 2010; Karanovic et al., 2012) started to revalidate and redefine some genera originally proposed by Jakobi (1972), as most of them remained valid and available names under the rules of the ICZN (1999), while at the same time synonymizing some others.

The latest family revision was published by Schminke (2010), who listed all 258 species described until then in the family Parastenocarididae, provisionally accepted 27 genera as valid (accepting most of those described by Jakobi, although mainly listing just their type species as valid members), and subdivided the family into two subfamilies. As a result of the Principle of Coordination, Parastenocaridinae Chappuis, 1940 has already (potentially) existed since 1940, with Parastenocaris as its type genus. In that respect, "Parastenocaridinae nov.", Schminke's (2010) most frequent way to refer to the taxon, is an error. He does, however, correctly call it "Parastenocaridinae Chappuis, 1940" in three places in his paper. 
On the other hand, he seems reluctant to call these two groups subfamilies, putting the word "subfamily" in quotes in the abstract and noting that such subgroups as he is proposing are "traditionally called subfamilies" (p. 344). Besides these instances, he does not use the term subfamily in the diagnosis section (pp. 361-362) or anywhere else. Still, the above quoted notation on p. 344 , together with the frequent notation "nov.", is enough to show that he is intentionally proposing a new taxon (Fontinalicaridinae) of subfamily rank (i.e., it is not some sort of informal or "provisional" or Phylocode-type unavailable taxon), and he explicitly designates its type genus. Therefore, we think, he has (barely) met the requirements for availability of new names. Due mostly to incomplete descriptions or absence of males, he was able to classify only 112 species of Parastenocarididae to the genus level, leaving a majority of them in the genus Parastenocaris. Division of the genus Parastenocaris into Parastenocaris s. str. and Parastenocaris s. l., as first proposed by Galassi and De Laurentiis (2004) and adopted with a different meaning by Schminke (2010), has neither nomenclatural bearing nor phylogenetic justification, as sensu stricto by definition must be part of sensu lato.

Two species presented in this paper belong to the brevipes group of species, defined by Lang (1948). Reid (1995) reviewed this group while redescribing Parastenocaris brevipes Kessler, 1913 from numerous localities in the Holarctic (although not from the type material or from topotypes) and synonymizing several previously described species with it, as well as the genus Biwaecaris Jakobi, 1972 with Parastenocaris Kessler, 1913. She also provided a list of morphological characters to define this group and included in it the following 11 species (besides P. brevipes): P. arctica Bortuzky, 1952; P. brincki Enckell, 1970; P. feuerborni Chappuis, 1931; P. hinumaensis Kikuchi, 1970; P. irenae Enckell, 1970; P. lanceolata Enckell, 1970; P. longicaudis Chappuis, 1931; P. longipoda Shen and Tai, 1973; P. noodti Enckell, 1970, P. oshimaensis Miura, 1962; P. singhalensis Enckell, 1970 (see Chappuis, 1931; Borutzky, 1952; Miura, 1962; Enckell, 1970; Kikuchi, 1970; and Shen and Tai, 1973). Karanovic $(2005 \mathrm{a} ; 2006)$ argued that $P$. arctica and $P$. longicaudis cannot be confidently included in this group for the lack of males, but he included $P$. palmerae Reid, 1991, described from the U.S.A. (Reid, 1991), which was not considered a member of this group by Reid (1995). Karanovic (2005a) provided a key to 14 species recognised by him as valid members of this group. In this paper we argue for a separate status of $P$. biwae Miura, 1969, which was synonymized with $P$. brevipes by Reid (1995), after a redescription of newly collected material from Japan. We also describe one new species from Korea, and include in this group six other species described subsequently: P. gayatri Ranga Reddy, 2001; P. gundlaka- mma Ranga Reddy, 2011; P. jane Karanovic, 2006; $P$. kimberleyensis Karanovic, 2005; P. savita Ranga Reddy, 2001; and P. sultej Ranga Reddy, 2011 (see Ranga Reddy, 2001; 2011; Karanovic, 2005a; 2006). This group of species contains the type species of the genus Parastenocaris ( $P$. brevipes) and cannot be separated from the bulk of species nomenclaturally without a proper revision of the whole family. Gallassi and Laurentiis (2004) repeated the major points of the review done by Reid (1995), and tried to subdivide the large genus Parastenocaris by calling the brevipes group Parastenocaris s. str., which is meaningless nomenclaturally. Most taxonomists, however, agree today that the brevipes group will be the revised genus Parastenocaris, once all other species are separated into different genera (Corgosinho et al., 2007; 2008; Schminke, 2008; 2010; Ranga Reddy and Defaye, 2009; Karanovic and Cooper, 2011a; 2011b; Karanovic et al., 2012).

\section{Materials And Methods}

All specimens of the Korean new species were collected by staff of the National Institute of Biological Resources (NIBR), Korea. Most of them were collected by the Karaman-Chappuis method, although some were also collected by various pumps from interstitial sediments. Specimens of the Japanese species were collected by the senior author also by the Karaman-Chappuis method. They were all fixed in $99 \%$ ethanol. Locality data and number of specimens are listed for each species separately, and all types and additionally examined specimens are deposited in the National Institute of Biological Resources.

Specimens were dissected and mounted on microscope slides in Faure's medium, which was prepared following the procedure discussed by Stock and von Vaupel Klein (1996), and dissected appendages were then covered by a coverslip. For the urosome or the entire animal two human hairs were mounted between the slide and coverslip, so the parts would not be compressed. By manipulating the coverslip carefully by hand, the whole animal or a particular appendage could be positioned in different aspects, making possible the observation of morphological details. During the examination water slowly evaporates and appendages eventually remained in a completely dry Faure's medium, ready for long term depositing. All line drawings were prepared using a drawing tube attached to a Leica MB2500 phase-interference compound microscope, with N-PLAN $(5 \times, 10 \times, 20 \times, 40 \times$ and $63 \times$ dry $)$ or PL FLUOTAR $(100 \times$ oil $)$ objectives. Specimens that were not drawn were examined in propylene glycol $(\mathrm{CH} 3 \mathrm{CH}(\mathrm{OH}) \mathrm{CH} 2 \mathrm{OH})$ and, after examination, were again preserved in $99.9 \%$ ethanol. Specimens 
for the scanning electron micrography were dehydrated in progressive ethanol concentrations, critical-point dried, coated in gold and observed under a LEO 1525 microscope on the in-lens detector, with working distances between 5.9 and $6.1 \mathrm{~mm}$ and accelerating voltages of 5 or $10 \mathrm{kV}$.

Morphological terminology follows Huys and Boxshall (1991), except for the caudal ramus setae numbering and small differences in the spelling of some appendages (antennula, mandibula, maxillula instead of antennule, mandible, maxillule), as an attempt to standardise the terminology for homologous appendages in different crustacean groups. Biospeleological terminology follows Humphreys (2000). Sensilla on all somites (body segments) were numbered consecutively with Arabic numerals from anterior to posterior part of the body and from dorsal to ventral side, to aid recognition of homologous structures; they are not intended as a novel terminology.

The cladistic analysis was performed on all 20 species of Parastenocaris Kessler, 1913 that we currently recognise as members of the brevipes group (including the new species described here) and three outgroup taxa: Dussartstenocaris idioxenos Karanovic and Cooper, 2012; Kinnecaris lakewayi Karanovic and Cooper, 2011; and Proserpinicaris young Karanovic, Cho and Lee, 2012. The first two outgroup species were described from Western Australian calcrete subterranean aquifers (Karanovic and Cooper, 2011a; 2011b), while the third outgroup was described recently from interstitial habitats in alluvial sediments in Korea (Karanovic et al., 2012), in some cases living sympatrically with populations of the new Parastenocaris species described in this paper. A total of 39 morphological characters were used in the analysis (see below). Characters were coded, optimized, and weighted using the computer program WinClada, version 1.00.08 (Nixon, 2002), and then analyzed using NONA, version 2 (Goloboff, 1999). Standard coding was used in the analysis: "0" representing a presumably plesiomorphic character state and " 1 ", a presumed apomorphy. Unknown values were coded "." and polymorphic characters within species are marked in the matrix with an asterisk (*). In four cases character states were coded as multistate (as transformation series $0,1,2$ ), while all others were coded as binary $(0,1)$. Characters No. 7 and 14 were downwighted to 0.5 . All other characters were weighted 1 , and all characters were coded as additive (representing ordered multistate character as a linked series of binary characters). One data matrix was created (Table 1) and the characters were analysed using Rachet Island Hopper searches with the following WinClada parameters: 1000 replications; 3 trees to hold; 5 characters to sample; 10 random constraint level and amb-poly $=(\mathrm{amb}$ - collapses a branch if the ancestor and descendant have different states under the same resolutions of multistate characters or of "-"; poly=treats trees as collapsed). Rachet Island Hopper is a method that searches tree space very effecti-

Table 1. Character matrix for the phylogenetic analysis of 20 species of the brevipes group of the genus Parastenocaris Kessler, 1913 and three outgroups: Proserpinicaris young Karanovic, Cho and Lee, 2012; Dussartstenocaris idioxenos Karanovic and Cooper, 2011; and Kinnecaris lakewayi Karanovic and Cooper, 2011. Symbols used: "0", presumed plesiomorphic character state; "1", presumed apomorphy; "-", unknown value; "*”, polymorphic character. See text for non-abbreviated species names, list of characters and states, and more details.

\begin{tabular}{|c|c|c|c|c|}
\hline Taxon \Char. & $\begin{array}{lllllllllll}0 & 1 & 2 & 3 & 4 & 5 & 6 & 7 & 8 & 9 & 10\end{array}$ & 123456788920 & 12345678930 & 12345678 \\
\hline Pro. & $\begin{array}{llllllllllll}1 & 0 & 0 & 0 & 0 & 0 & 0 & 0 & 1 & 0 & 0\end{array}$ & $\begin{array}{lllllllllll}0 & 0 & 0 & 1 & 1 & 1 & 1 & 1 & 1 & 0\end{array}$ & $\begin{array}{llllllllll}1 & 0 & 1 & 0 & 1 & 1 & 0 & 0 & 0 & 1\end{array}$ & $\begin{array}{lllllllll}0 & 0 & 0 & 0 & 0 & 0 & 1 & 1\end{array}$ \\
\hline enos & $\begin{array}{lllllllllll}1 & 1 & 1 & 0 & 0 & 0 & 0 & 0 & 1 & 1 & 0\end{array}$ & $\begin{array}{lllllllllll}0 & 0 & 1 & 0 & 0 & 1 & 1 & 1 & 1 & 0\end{array}$ & $\begin{array}{llllllllll}0 & 0 & 1 & 0 & 0 & 0 & 0 & 0 & 0 & 1\end{array}$ & $\begin{array}{llllllll}0 & 0 & 0 & 0 & 0 & 1 & 2 & 1\end{array}$ \\
\hline Kin. lakewayi & $\begin{array}{lllllllllll}0 & 0 & 1 & 1 & 1 & 1 & 0 & 0 & 1 & 0 & 1\end{array}$ & $\begin{array}{llllllllll}1 & 0 & 0 & 0 & 1 & 1 & 0 & 0 & 0 & 0\end{array}$ & $\begin{array}{llllllllll}0 & 0 & 1 & 0 & 0 & 0 & 0 & 0 & 0 & 1\end{array}$ & $\begin{array}{llllllll}0 & 0 & 0 & 1 & 0 & 0 & 0 & 0\end{array}$ \\
\hline Par. $b$ & $\begin{array}{lllllllllll}0 & 0 & 0 & 0 & 1 & 1 & 0 & 0 & 1 & 0 & 1\end{array}$ & $\begin{array}{llllllllll}0 & 1 & 0 & 0 & 0 & 1 & 0 & 0 & 0 & 0\end{array}$ & $\begin{array}{lllllllllll}1 & 0 & 1 & 1 & 1 & 1 & 1 & 2 & 1 & 1\end{array}$ & $\begin{array}{lllllllll}1 & 1 & 0 & 1 & 1 & 0 & 1 & 0\end{array}$ \\
\hline Par. $l$ & $\begin{array}{lllllllllll}0 & 0 & 0 & 0 & 1 & 1 & 0 & 0 & 1 & 0 & 1\end{array}$ & $\begin{array}{llllllllll}0 & 1 & 0 & 0 & 0 & 1 & 0 & 0 & 0 & 0\end{array}$ & $\begin{array}{lllllllllll}1 & 0 & 1 & 0 & 1 & 1 & 1 & 2 & 1 & 1\end{array}$ & $\begin{array}{lllllllll}1 & 1 & 0 & 1 & 1 & 0 & 1 & 0\end{array}$ \\
\hline Par. $b$ & $-0000-\begin{array}{lllllll}0 & 0 & 1 & 1 & 1\end{array}$ & $1----1-0001$ & $\begin{array}{lllllllllll}1 & 1 & 1 & 2 & 0 & 1 & 1 & 1 & 1 & 1\end{array}$ & $\begin{array}{llllllll}0 & 1 & 0 & - & 0 & 1 & 2 & -\end{array}$ \\
\hline Par. feuerbor & $-110--00111$ & $0-00--0002$ & $\begin{array}{lllllllllll}1 & 0 & 0 & 0 & 1 & 1 & 1 & 1 & 1 & 1\end{array}$ & $\begin{array}{lllllllll}0 & 1 & 0 & 1 & 1 & 0 & 1 & -\end{array}$ \\
\hline Par. 8 & $-0000-\begin{array}{lllllll}0 & 0 & 1 & 0 & 1\end{array}$ &  & $\begin{array}{lllllllllll}1 & 0 & 1 & 0 & 1 & 1 & 1 & 1 & 1 & 1\end{array}$ & $\begin{array}{lllllllllll}0 & 1 & 0 & 1 & 1 & 0 & 1 & 0\end{array}$ \\
\hline Par. & $\begin{array}{llllllllllll}0 & 0 & 0 & 0 & 1 & 1 & 0 & 0 & 1 & 0 & 1\end{array}$ & $0-0 \begin{array}{llllllll}0 & 1 & 0 & 0 & 0 & 0 & 1 & 1\end{array}$ & $\begin{array}{llllllllll}1 & 0 & 0 & 0 & 1 & 1 & 1 & 2 & 1 & 1\end{array}$ & $\begin{array}{lllllllll}0 & 0 & 0 & 1 & 1 & 0 & 1 & 0\end{array}$ \\
\hline Par. hinu & $\ldots \ldots-\ldots=01111$ & 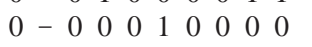 & $\begin{array}{llllllllll}1 & 1 & 1 & 2 & 1 & 1 & 1 & 2 & 0 & 1\end{array}$ & $\begin{array}{lllllllll}0 & 1 & 0 & 1 & 1 & 0 & 0 & 0\end{array}$ \\
\hline Par. $i$ & $-0 \begin{array}{lllllllll}0 & 0 & 0 & - & -0 & 0 & 1 & 1 & 1\end{array}$ & $0---\begin{array}{llllll}1 & 0 & 1 & 0 & 0\end{array}$ & $\begin{array}{lllllllllll}1 & 1 & 1 & 2 & 1 & 1 & 1 & 1 & 1 & 1\end{array}$ & $\begin{array}{lllllllll}0 & 0 & 0 & 1 & 0 & 0 & 1 & -\end{array}$ \\
\hline Par. J & $\begin{array}{llllllllllll}0 & 0 & 0 & 0 & 0 & 1 & 0 & 0 & 1 & 1 & 1\end{array}$ & $\begin{array}{llllllllll}1 & 0 & 0 & 0 & 0 & 1 & 0 & 0 & 0 & 0\end{array}$ & $\begin{array}{lllllllllll}0 & 0 & 1 & 0 & 1 & 1 & 1 & 1 & 1 & 1\end{array}$ & 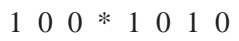 \\
\hline Par. $k$ & $\begin{array}{llllllllllll}1 & 1 & 1 & 0 & 1 & 1 & 1 & 0 & 1 & 1 & 1\end{array}$ & 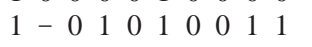 & $\begin{array}{lllllllllll}0 & 0 & 0 & 0 & 1 & 1 & 1 & 1 & 1 & 1\end{array}$ & $\begin{array}{lllllllll}0 & 1 & 0 & 0 & 1 & 1 & 2 & 0\end{array}$ \\
\hline Par. $k$ & $\begin{array}{lllllllllll}0 & 0 & 0 & 0 & 1 & 1 & 0 & 0 & 1 & 0 & 1\end{array}$ & $\begin{array}{llllllllll}0 & 1 & 0 & 0 & 0 & 1 & 0 & 0 & 0 & 0\end{array}$ & $\begin{array}{lllllllllll}1 & 0 & 1 & 1 & 1 & 1 & 1 & 2 & 1 & 1\end{array}$ & $\begin{array}{lllllllll}1 & 1 & 0 & 1 & 1 & 0 & 1 & 0\end{array}$ \\
\hline Par. & $-0 \begin{array}{llllllllll}0 & 0 & 0 & - & -0 & 0 & 0 & 1 & 1 & 1\end{array}$ & $0----1-0001$ & $\begin{array}{lllllllllll}1 & 1 & 1 & 2 & 1 & 1 & 1 & 1 & 1 & 1\end{array}$ & $\begin{array}{llllllll}0 & 1 & 1 & - & 1 & 0 & 1 & -\end{array}$ \\
\hline Par. $l$ & 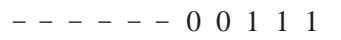 & $0-100-00002$ & $\begin{array}{lllllllllll}1 & 0 & 1 & 1 & 1 & 1 & 1 & 1 & 1 & 0\end{array}$ & $\begin{array}{llllllll}0 & 1 & 0 & 1 & 1 & 1 & 2 & -\end{array}$ \\
\hline Par. & $\begin{array}{lllllllllll}1 & 0 & 0 & 0 & 1 & 0 & 0 & 0 & 0 & 0 & 1\end{array}$ & $\begin{array}{llllllllll}0 & 1 & 1 & 1 & 0 & 0 & 0 & 0 & 0 & 1\end{array}$ & $\begin{array}{lllllllllll}1 & 0 & 1 & 1 & 1 & 1 & 1 & 1 & 1 & 1\end{array}$ & $\begin{array}{lllllllll}0 & 1 & 0 & 1 & 0 & 0 & 1 & 0\end{array}$ \\
\hline Par. & $\begin{array}{lllllllllll}0 & 0 & 0 & - & -1 & 0 & 1 & 1 & 1\end{array}$ & $0-\ldots-100000$ & $\begin{array}{lllllllllll}1 & 1 & 1 & 2 & 1 & 1 & 1 & 1 & 1 & 1\end{array}$ & $\begin{array}{llllllll}0 & 0 & 0 & 0 & 1 & 1 & 2 & -\end{array}$ \\
\hline Par. & $\begin{array}{lllllllll}- & - & - & - & 0 & 1 & 1 & 0 & 1\end{array}$ & $0-\cdots-\cdots \begin{array}{lllllllll}0 & 0 & 0 & 1\end{array}$ & $\begin{array}{llllllllll}1 & 1 & 1 & 2 & 1 & 1 & 1 & 1 & 0 & 1\end{array}$ & $\begin{array}{lllllllll}0 & 1 & 1 & 1 & 1 & 0 & 0 & 0\end{array}$ \\
\hline Par. & $\begin{array}{lllllllllll}0 & 0 & 0 & 0 & - & - & 0 & 0 & 1 & 0 & 1\end{array}$ & $\begin{array}{cccccccccc} & -0 & 1 & 0 & 1 & 0 & 1 & 1 & 1\end{array}$ & $\begin{array}{lllllllllll}1 & 0 & 1 & 0 & 1 & 1 & 1 & 2 & 1 & 1\end{array}$ & $\begin{array}{llllllll}0 & 0 & 0 & 1 & 0 & 0 & 0 & 0\end{array}$ \\
\hline Par. & $-\begin{array}{llllllllll}0 & 0 & 0 & - & - & 0 & 0 & 1 & 0 & 1\end{array}$ & $1-0 \begin{array}{llllllll}0 & 0 & 0 & 1 & 0 & 0 & 0 & 0\end{array}$ & $\begin{array}{lllllllllll}0 & 0 & 1 & 0 & 1 & 1 & 1 & 1 & 1 & 0\end{array}$ & $\begin{array}{lllllllll}0 & 1 & 0 & 0 & 1 & 0 & 0 & 0\end{array}$ \\
\hline Par. & $\begin{array}{lllllllllll}-0 & 0 & 0 & - & - & 0 & 0 & 1 & 0 & 1\end{array}$ & $0-\ldots-1 \quad 0 \quad 0 \quad 01$ & $\begin{array}{lllllllllll}1 & 1 & 1 & 2 & 1 & 1 & 1 & 1 & 1 & 1\end{array}$ & $010-10-101-$ \\
\hline Par. sultej & $\begin{array}{llllllllllll}1 & 1 & 1 & 0 & 0 & 0 & 0 & 0 & 1 & 0 & 1\end{array}$ & $0-1 \quad \begin{array}{llllllll}1 & 0 & 1 & 0 & 0 & 0 & 0\end{array}$ & $\begin{array}{lllllllllll}1 & 1 & 1 & 2 & 0 & 1 & 1 & 1 & 1 & 1\end{array}$ & $\begin{array}{lllllllll}0 & 1 & 0 & 1 & 0 & 0 & 1 & 0\end{array}$ \\
\hline
\end{tabular}


vely by reducing the search effort spent on generating new starting points and retaining more information from existing results of tree searches. Only characters No. 3 and 8 were uninformative (Table 1 ).

The 39 morphological characters used in the cladistic analysis are listed below, with character states in brackets (note: NONA requires characters to start with 0 , rather than 1):

0. Body, cuticular pits: present (0); absent (1).

1. Urosome, any cuticular windows: present (0); absent (1).

2. Urosome, dorsal cuticular windows: absent (0); present (1)

3. Urosome, lateral cuticular windows: present (0); absent (1).

4. Third urosomite, number of sensilla: more than three pairs (0); three pairs (1).

5. Fourth urosomite, number of sensilla: more than three pairs (0); three pairs (1).

6. Anal somite, dorsal spinules: absent (0); present (1).

7. Anal operculum: smooth (0); with dorsal spinules (1).

8. Caudal ramus, unguiform process: present (0); absent (1).

9. Caudal ramus, number of lateral setae: three (0); two or less (1).

10. Caudal ramus, position of lateral seta in relation to dorsal: anterior (0); same (1).

11. Caudal ramus, lateral setae insertion: at midlength or in anterior part $(0)$; in posterior half $(1)$.

12. Caudal ramus, position of cuticular pore: posterior (0); central (1).

13. Male antennule, fourth segment with process: present (0); absent (1).

14. Male antennule, sixth segment with process: present (0); absent (1).

15. Male antennule, aesthetasc on fourth segment: as in female (0); inflated (1).

16. Male first leg, basis, inner seta: present (0); absent (1).

17. Female third leg, endopod: spiniform (0); linguiform (1).

18. Male third leg, first exopodal segment, inner margin: smooth (0); with process (1).

19. Male third leg, first exopodal segment, outer proximal margin: smooth (0); with spinules (1).

20. Male third leg, first exopodal segment, outer spine: as long as apophysis (0); shorter (1); very small or absent (2).

21. Male third leg, second exopodal segment (apophysis): bifid (0); not bifid (1).

22. Male third leg, endopod: present (0); absent (1).

23. Male third leg, endopod: distinct segment (0); reduced or fused to apical element (1).

24. Male third leg, endopod, armature element: seta (0); minute (1); absent (2).

25. Male fourth leg, basis, spinules on inner margin: present (0); absent (1).

26. Male fourth leg, basis, hyaline processes: absent (0); present (1).

27. Male fourth leg, basis, position of hyaline processes: between exopod and endopod or absent $(0)$; on inner margin (1).

28. Male fourth leg, basis, number of hyaline processes: none or one (0); two (1); three (2).

29. Male fourth leg, first exopodal segment, inner margin: straight or slightly concave (0); deeply concave (1).

30. Male fourth leg, endopod: two-segmented (0); onesegmented (1).

31. Male fourth leg, endopod: unilobate apically (0); bilobate apically (1)

32. Male fourth leg, endopod: armed apically (0); unarmed (1).

33. Male fourth leg, endopod: ornamented with spinules (0); smooth (1).

34. Female fifth leg, spinules along inner margin: present (0): absent (1).

35. Male fifth leg, inner-distal process: present (0); absent (1).

36. Male fifth leg, number of exopodal setae: three or more (0); two (1).

37. Male fifth leg, outermost exopodal seta: well developed (0); reduced in size (1); absent (2).

38. Female sixth legs fusion: narrow or absent (0); complete, resulting in long flap (1).

\section{Systematics}

Family Parastenocarididae Chappuis, 1940

Subfamily Parastenocaridinae Chappuis, 1940

Genus Parastenocaris Kessler, 1913

\section{Parastenocaris biwae Miura, 1969}

(Figs. 1-3)

Synonymy. Parastenocaris biwae Miura, 1969, p. 40, fig. 1-15; Dussart and Defaye, 1990, p. 254.

Parastenocaris brevipes Kessler, 1913: Reid, 1995, p. 177, fig. $2 \mathrm{i}$.

Type locality. Japan, Shiga Prefecture, Lake Biwa, western shore, Shirahige, sandy beach.

Specimens examined. Two males (NIBRIV0000232643 and NIBRIV0000232644) and one female (NIBRIV0000 232645), each dissected on one slide; Japan, Shiga Prefecture, Lake Biwa drainage area, confluence of Seto and Daido rivers, sandy/gravely beach, 27 September 2009, 
leg. T. Karanovic.

Redescription. Male (based on two newly collected specimens): Total body length, measured from tip of rostrum to posterior margin of caudal rami (excluding caudal setae), from 600 to $612 \mu \mathrm{m}$. Preserved specimen colourless. Nauplius eye absent. Body composed of prosome (consisting of cephalothorax and three free pedigerous somites (first pedigerous fused to cephalothorax)), and urosome (consisting of fifth pedigerous somite, genital somite, four abdominal somites, and caudal rami). Podoplean boundary between prosome and urosome inconspicuous. Habitus (Fig. 1A) cylindrical and very slender, without any demarcation between prosome and urosome; prosome/urosome ratio about 0.8 in dorsal view; greatest width in dorsal view at posterior end of cephalothorax but hard to establish (fourth pedigerous somites only slightly narrower); free prosomal somites in lateral view as wide as cephalothorax or urosome. Body length/width ratio about 9.1; cephalothorax 1.1 times as wide as genital somite. Free pedigerous somites without any lateral or dorsal expansions, all connected by well developed arthrodial membranes. Hyaline fringes of all somites smooth, very narrow and hard to distinguish from arthroidal membranes, especially dorsally, except in preanal somite, where hyaline fringe well developed (Fig. 1A). Integument weakly sclerotized, smooth but covered with shallow pits on all somites and caudal rami, ornamented only with sensilla and pores (no spinules, except on posterior margin of caudal rami ventrally), with round dorsal double cuticular window on cephalothorax, trapezoidal simple dorsal cuticular window on genital, and elongated simple dorsal windows on three postgenital somites (Fig. 1A). Pleural areas of cephalothorax and free pedigerous somites not well developed, cephalic appendages and coxae of swimming legs clearly exposed in lateral view.

Rostrum(Fig. 1A) small, membranous, not demarcated at base, ornamented with two large dorsal sensilla (No. 1), linguiform but with pointed tip, hardly reaching distal margin of first antennular segment, about as long as wide.

Cephalothorax (Fig. 1A, C) about 1.8 times as long as wide in dorsal view; representing $20 \%$ of total body length. Surface of cephalic shield ornamented with 16 pairs of large sensilla; with a dense pattern of cuticular pits of different sizes; five pairs of sensilla surround double cuticular window, but its surface completely smooth; pairs of sensilla Nos. 12-16 belong to first pedigerous somite incorporated into cephalothorax. Athroidal membrane between cephalothorax and second pedigerous somite (first free) wider than between any other somites.

Second pedigerous somite (Fig. 1A) slightly narrower than posterior half of cephalothorax in dorsal view, with four pairs of large sensilla (three dorsal and one lateral; Nos. 17-20; note lateral pair of sensilla No. 20 not visible in Fig. 1A), and with unpaired dorsal pore in anterior half. Postero-dorsal pair of sensilla (No. 18) serially homologous to pair No. 13 on first pedigerous somite, but for other pairs serial homology not that obvious.

Third pedigerous somite (Fig. 1A) slightly wider and shorter than second pedigerous, with four pairs of large sensilla (Nos. 21-24), also with unpaired dorsal pore; all sensilla serially homologous to those on second pedigerous somite (i.e. pairs Nos. 17 and 21, Nos. 18 and 22, Nos. 19 and 23, and Nos. 20 and 24); serial homology of dorsal cuticular pores between these two somites not that clear.

Fourth pedigerous somite (Fig. 1A) widest and longest free prosomal somite in dorsal view, with only three pairs of large posterior sensilla (two dorsal and one lateral; Nos. 25-27), with arched sutures in anterior part dorsally and unpaired cuticular pore in between them. Serial homology of sensilla between third and fourth pedigerous somites not that clear, except for lateral pairs (Nos. 24 and 27).

First urosomite (=fifth pedigerous somite) (Fig. 1A) slightly narrower and shorter than fourth pedigerous somite, also with three pairs of large posterior sensilla(Nos. 28-30), without arched dorsal sutures or cuticular pores. All three pairs of sensilla serially homologous to those on fourth pedigerous somite (i.e. Nos. 25 and 28, Nos. 26 and 29, and Nos. 27 and 30; note: lateral pair of sensilla No. 30 not visible in dorsal view in Fig. 1A).

Second urosomite (=genital somite) (Fig. 1A, D) slightly narrower and longer than first urosomite, about 1.2 times as wide as long in ventral view, with trapezoidal small cuticular window in anterior half, also with three pairs of posterior sensilla (Nos. 31-33), but dorsal pair (No. 31) closer to each other than in first urosomite; single longitudinally placed spermatophore inside longer than somite. Dorsal pair of sensilla (No. 31) probably serially homologous to that on first urosomite (No. 28), but other two pairs probably not serially homologous.

Third urosomite (Figs. 1A) about as long as second urosomite but slightly narrower, with shorter but much wider dorsal cuticular window, and with three pairs of large posterior sensilla (Nos. 34-36). All sensilla probably serially homologous to those on second urosomite, but dorsal pair (No. 34) more widely spaced.

Fourth urosomite (Fig. 1A) with slightly larger dorsal cuticular window, but similar size and same ornamentation, consisting of also three pairs of large posterior sensilla (Nos. 37-39). All sensilla serially homologous to those on third usoromite, but dorsal pair (No. 37) slightly closer to each other.

Fifth urosomite (=preanal somite) (Fig. 1A) slightly narrower and longer than fourth urosomite, with largest dorsal cuticular window of all urosomites, and without any surface ornamentation; hyaline fringe well defined on all sides. 




Fig. 1. Parastenocaris biwae Miura, 1969, male: A. habitus, dorsal view. B. anal somite and caudal rami, ventral view. C. cephalothoracic shield, lateral view (dissected). D. anal somite with spermatophore inside, ventral view. E. antennule, ventral view. F. antenna, dorsal view. Arabic numerals indicating pairs of sensilla numbered consecutively from anterior to posterior part of the body and from dorsal to ventral side. Scale bars $100 \mu \mathrm{m}$ for all. 
Sixth urosomite (=anal somite) (Figs. 1A, B) about 1.5 times as long as and 0.9 times as wide as preanal somite, ornamented with pair of large dorsal sensilla at base of anal operculum (No. 40), pair of large lateral cuticular pores in anterior half, and pair of ventral pores at base of caudal rami (no spinules on ventral surface), in addition to numerous shallow cuticular pits. Anal operculum well developed, unornamented on outer surface, with smooth and convex distal margin, not reaching posterior end of anal somite, representing $53 \%$ of somite's width. Anal sinus wide opened, ornamented with two long diagonal rows of slender spinules on ventral side, and one additional row on dorsal side (inner side of anal operculum).

Spermatophore (Figs. 1D, 2) about 2.3 times as long as wide, kidney-shaped, with long and narrow, curved neck.

Caudal rami (Fig. 1A, B) slender, about 3.2 times as long as greatest width (ventral view) and about 0.7 times as long as anal somite, cylindrical but tapering towards posterior end, slightly divergent, with space between them about 1.5 times of one ramus width; armed with seven elements (three lateral, one dorsal, and three apical). Ornamentation consists of large lateral cuticular pore at about $2 / 3$ of ramus length, and posterior ventral row of several spinules along posterior margin. Dorsal seta slender and smooth, inserted closer to inner margin at midlength, about 0.8 times as long as caudal ramus, triarticulate basally (inserted on two pseudo-joints). Lateral setae slender and smooth, inserted very close to each other also at midlength, two larger ones more anteriorly and minute one in between and more posteriorly. Anterior lateral seta which inserted more dorsally longest, half as long as ramus, 2.3 times as long as ventral anterior seta, and about five times as long as minute (distal) seta. Inner apical seta smooth, inserted close to ventral margin, about 0.8 times as long as ramus. Middle apical seta strongest, without breaking plane, smooth, about 4.7 times as long as ramus, pointing posteriorly, with slightly curled tip inwardly. Outer apical seta also without breaking plane and smooth, relatively strong basally but much shorter, about 0.9 times as long as ramus, inserted close to dorsal surface and pointing latero-posteriorly.

Antennula (Fig. 1E) shorter than cephalothorax, slender, eight-segmented, prehensile and strongly digeniculate, ornamented with six ventral spinules on first segment distally, and with ribbed elongated chitinous plate on anterior surface of sixth segment. First segment very short, while second longest. Geniculation between third and fourth and between sixth and seventh segments; last two segments at $90^{\circ}$ angle. Distal anterior corner of seventh segment produced into very small spiniform process, but larger proximal spiniform process present on fifth segment on anterior surface. Long aesthetasc on fifth segment reaching beyond tip of appendage for length of last segment, fused basally to slightly longer seta, relatively slender and blunt distally; much shorter and more slender apical aesthetasc on seventh segment, fused basally to two setae (acrotheck). Setal formula: 0.6.4.2.4.0.1.9. All setae slender and all, except largest seta on second segment, smooth; most setae with pore on tip; proximalmost seta on second segment unipinnate with several long spinules along anterior surface, much shorter than two large setae on fifth segment or longest apical seta on eighth segment (latter probably longest); only seta on eighth segment minute.

Antenna (Fig. 1F) relatively stout and short, composed of coxa, allobasis, one-segmented endopod, and one-segmented exopod. Coxa very short, unarmed, ornamented with three short spinules. Allobasis about three times as long as wide, unarmed but ornamented with two rows of large spinules on anterior surface. Endopod 0.8 times as long as allobasis and nearly three times as long as wide, with two parallel surface frills subdistally, ornamented with large spinules along anterior surface, armed laterally with two short spines (proximal one shorter) and apically with five strong elements (two geniculate). Exopod minute, cylindrical, about twice as long as wide, unornamented but armed with single apical seta, which three times as long as segment. All antennal armature unipinnate.

Labrum large and triangular in lateral view, with narrow and straight cutting edge, without any ornamentation on anterior surface, with several parallel rows of spinules along cutting edge (those on outer distal corners strongest).

Paragnaths strongly fused into trilobite structure, with numerous distal rows of slender short spinules on lateral lobes, one distal row of minute spinules on central lobe, and another transverse row of 10 very long spinules on posterior surface of central lobe at about $2 / 3$ of its length.

Mandibula with narrow cutting edge on elongated coxa, armed with one complex tooth ventrally, one unipinnate seta dorsally, and several smaller teeth and/or spinules in between. Palp one-segmented, cylindrical, about 2.5 times as long as wide, unornamented, and armed apically with two smooth and subequal setae, each with pore on tip.

Maxillula with relatively large praecoxa, arthrite rectangular, about 1.5 times as long as wide from lateral view, ornamented with single spinule on posterior surface near dorsal margin, armed with lateral strong seta and four apical elements (probably three spines and one strong seta; apical spines with crown of spinules on tip, resembling small hands). Coxal endite armed with one smooth seta apically. Basis slightly longer than coxal endite, armed with three apical setae (two smooth and slender, one curved and unipinnate), and single minute lateral seta. Endopod and exopod absent (fused to basis without trace), minute seta on basis probably representing remnants of exopodal armature. All coxal and basal setae, as well as 
smooth lateral seta on praecoxa, with pore on tip.

Maxilla composed of syncoxa, basis, and one-segmented endopod, ornamented with row of five spinules on inner side of syncoxa proximally, and with arched row of six spinules on posterior side of syncoxa close to outer margin. Syncoxa with two endites, basal armed with single smooth seta apically, distal armed with two smooth and one pinnate seta apically. Basis drawn out into strong and unipinnate claw, without seta at base, with cuticular pore on convex margin near distal tip. Endopod represented by minute segment, armed with two smooth subequal apical setae. All setae on maxilla with pore on tip.

Maxilliped with short and relatively strong syncoxa, unarmed and unornamented; basis slender, almost five times as long as wide and three times as long as syncoxa, unornamented and unarmed; endopod represented by short curved claw, swollen at base as indication of ancestral one-segmented endopod, ornamented with several strong spinules along concave margin distally, about 0.7 times as long as basis.

First swimming leg (Fig. 2A) with unarmed praecoxa, coxa, and intercoxal sclerite. Intercoxal sclerite very small, with narrow and concave distal margin and smooth. Praecoxa ornamented with several rows of minute spinules on anterior surface. Coxa with posterior row of large spinules on posterior surface and close to outer margin. Basis somewhat shorter than coxa, pentagonal, ornamented with bunch of large spinules on outer margin, another bunch along distal margin at base of endopod, and several long spinules on inner margin proximally; armed with single short seta on outer margin. Exopod threesegmented, armed with one outer spine on first segment and four elements on third segment (two outer spines and two apical geniculate setae); ornamented with few large spinules along outer margin and distally on all segments. Endopod two-segmented, about as long as exopod; first segment reaching slightly beyond distal margin of second exopodal segment, about four times as long as wide, unarmed, ornamented with two short rows of large spinules on outer margin, one longer row of even longer spinules on inner margin, and three spinules on anterior surface along distal margin; second segment armed apically with long geniculate seta and much shorter spine; endopodal geniculate seta 1.5 times as long as entire endopod, 1.2 times as long as larger geniculate exopodal seta, and almost 2.4 times as long as outer spine on endopod. All exopodal and endopodal armature unipinate along outer margin. Endopod on one leg in one male deformed (Fig. 2A), all others normal.

Second swimming leg (Fig. 2B) with smooth praecoxa and intercoxal sclerite. Intercoxal sclerite large, trapezoidal, with deeply concave distal margin. Praecoxa triangular and large. Coxa short, rhomboidal, with diagonal row of small spinules on anterior surface and two shorter rows of spinules along distal margin on posterior surface. Basis larger than coxa, semicircular, unarmed, ornamented with row of spinules on outer margin and another arched row of spinules at base of endopod. Exopod three -segmented, ornamented with large spinules along outer margin, and with distal hyaline frills on each segment on inner side; first segment armed with single outer spine; second segment unarmed; third segment armed with three long elements (probably outer spine and two apical setae), innermost one 1.55 times as longer as entire exopod; all exopodal armature bipinnate. Endopod one-segmented, cylindrical and slender, 5.3 times as long as wide, reaching 3/4 of first exopodal segment in length, ornamented with four large spinules along apical margin; armed apically with single smooth seta, which about 0.9 times as long as segment and pointing inwards.

Third swimming leg (Fig. 2C-E) with smooth intercoxal sclerite, which largest of all legs, trapezoidal, and with short and concave distal margin. Praecoxa not well defined on anterior surface, triangular on posterior surface, about as large as in second leg, unarmed, and unornamented. Coxa rectangular, with arched row of large spinules on anterior surface, and two rows of spinules along posterior margin on posterior surface (outer minute). Basis robust, ornamented with long row of large spinules and one pore on anterior surface, armed with outer long and slender seta; distal inner corner of basis produced distally as bulbous soft semicircular lobe, partly shielding endopod. Endopod represented with single smooth and minute armature element, inserted on inner margin at 3/4 of basis length, shorter but stronger than spinules on anterior surface. Exopod with both segments fused; ancestral proximal segment 2.5 times as long as wide, curved inwards and with thin hyaline lamella along inner margin, and three strong and short chitinous beaks on posterior surface, ornamented with two or three minute spinules on distal outer corner; armed subapically with simple, strong, smooth and inwardly curved spine, which about as long as apophysis and more or less flat distally; ancestral distal segment (apophysis) cylindrical, oriented slightly inwards, ornamented with single pore on anterior surface; armed with single short element on top, which leaf-like, with very thin cuticulum, more or less ovoid.

Fourth swimming leg (Fig. 2F) with smooth praecoxa and intercoxal sclerite. Intercoxal sclerite shorter and smaller than in third, with equally long and concave distal margin. Praecoxa small and triangular. Coxa rhomboidal, slightly larger than in second leg, unarmed, ornamented with short distal row of minute spinules on posterior surface. Basis large and more or less rectangular, armed with single smooth outer seta, ornamented with two minute spinules on outer margin at base of outer seta, and with three huge chitinous spiniform process on inner distal corner; anterior process bilobate distally and very 


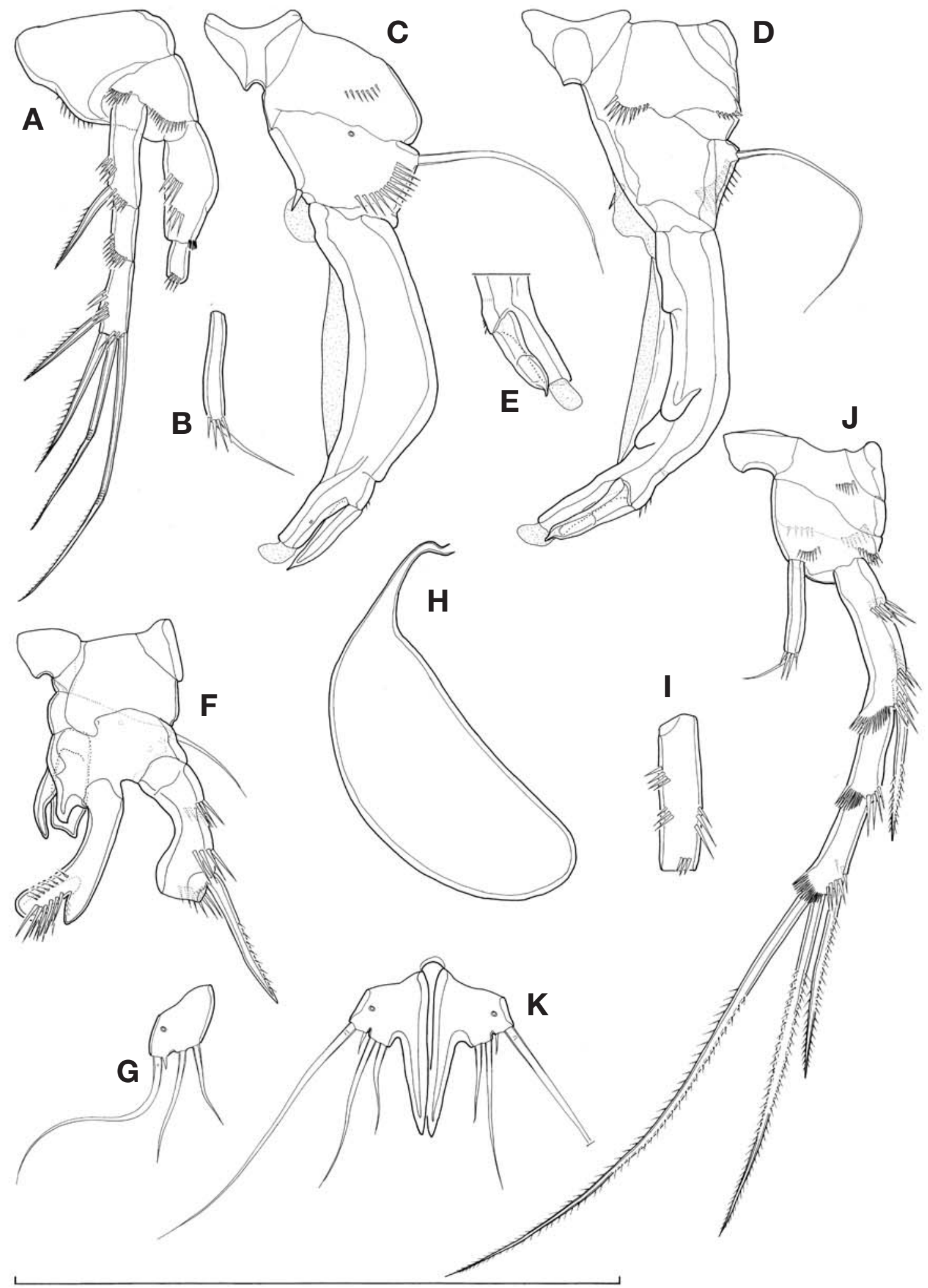

Fig. 2. Parastenocaris biwae Miura, 1969, A-G. male, H-K. female: A. first swimming leg with abnormal endopod (undissected). B. endopod of second swimming leg. C. third swimming leg, anterior view (undissected). D. third swimming leg, posterior view (dissected and mounted). E. tip of third leg, posterior view. F. fourth swimming leg without last two exopodal segments, posterior view. G. fifth leg, anterior view. H. spermatophore. I. first endopodal segment of first swimming leg, anterior view. J. second swimming leg, anterior view. K. fifth legs, anterior view. Scale bar $100 \mu \mathrm{m}$ for all. 
wide; inner process spiniform and curved outward, longest; posterior process shortest but most strongly chitinized. Exopod three-segmented, ornamented with few large spinules along outer margin on all segments, and with hyaline frills distally on inner side; first segment with strongly concave and smooth inner margin, armed with single outer spine; second segment unarmed; third segment armed with outer spine and long and strong apical seta; apical seta 1.2 times as long as entire exopod, and more than twice as long as outer spine. Endopod onesegmented, about as strong but longer than first exopodal segment, cylindrical proximally and bilobate distally, with inner lobe longer and stronger, ornamented with several rows of very long spinules; inner lobe smooth and with thin cuticulum.

Fifth leg (Fig. 2G) simple short cuticular plate, almost rectangular in shape, ornamented with single pore on anterior surface and single spinule at base of outermost seta, armed with three smooth setae; outermost seta (ancestral basal one) longest, almost three times as long as entire leg; middle seta (probably ancestral outer endopodal) much shorter, 1.7 times as long as leg, and 1.4 times as long as innermost seta (inner endopodal). Fifth legs distinct at base, with small space between them, pointing caudally, not reaching distal margin of fifth pedigerous somite.

Sixth legs (Fig. 1D) smooth, unarmed and unornamented, forming simple large operculum covering gonopore, probably both fused together or right one reduced and left one enlarged, representing 55\% of somite's width.

Female (based on single newly collected specimen): Body length, excluding caudal setae, $584 \mu \mathrm{m}$. Habitus, ornamentation of prosomites, colour and nauplius eye similar to male, except genital and first abdominal somite fused into double somite and habitus slightly less slender.

Genital double somite (Fig. 3A-C) about as wide as long (ventral view), without any trace of subdivision, with oval dorsal cuticular window in anterior half, which much larger than that in male (originating from fused windows of two ancestral somites). Genital complex (Fig. 3B) occupying anterior ventral half of genital double somite; genital apertures covered by vestigial sixth legs; median copulatory pores also covered by fused sixth legs; seminal receptacles small, bell-shaped, with strongly sclerotized lateral walls; copulatory duct very short and weakly sclerotized. All posterior sensilla homologous to those on male third urosomite, while all sensilla from male second urosomite missing except lateral pair (No. 32).

Third, fourth (preanal), and fifth (anal) urosomites very similar to male (Fig. 3A, B).

Caudal rami (Fig. 3A, B) slightly shorter in proportion to anal somite than in male, about 3.7 times as long as wide in ventral (or dorsal) view, and slightly less diver- gent, but also cylindrical and armed and ornamented as in male.

Antennula seven-segmented, ornamented on first segment with few minute spinules on ventral surface, not geniculate, with slender aesthetasc on fourth segment, not reaching beyond tip of appendage, and more slender apical aesthetasc on seventh segment, which fused basally to two apical setae; proximal aesthetasc much more slender than in male; setal formula: 0.4.5.2.1.0.9. All setae, except proximalmost one on second segment, smooth, and most setae with pore on tip.

Antenna, labrum, paragnaths, mandibula, maxillula, maxilla, maxilliped, first swimming leg (Fig. 2I), and second swimming leg (Fig. 2J) same as in male.

Third swimming leg (Fig. 3C) with smooth praecoxa and intercoxal sclerite. Coxa with three large spinules on anterior surface, and two rows of spinules along distal margin on posterior surface, unarmed. Basis ornamented with several large spinules on outer margin distally and another row of smaller spinules at base of endopod, armed with very long and smooth outer seta, which 0.8 times as long as entire exopod. Exopod two-segmented, ornamented with large spinules along outer margin, both segments with hyaline frills distally on inner side; first segment armed with single outer spine; second with outer spine and apical strong seta; all elements bipinnate; apical seta 1.5 times as long as entire exopod. Endopod one-segmented, small, cylindrical and unornamented, armed with apical spiniform bipinnate element on tip, which basally fused to segment, reaching $4 / 5$ of first exopodal segment in length.

Fourth swimming leg (Fig. 3D) without spiniform processes on basis. Endopod one-segmented, slender and long, cylindrical, curved inwards, ornamented with apical row of five large spinules at base of apical spine (no lateral spinules on inner margin); apical spine not distinct at base, bipinnate and robust, and about 0.7 times as long as endopod; endopod with apical spine almost reaching posterior margin of third exopodal segment in length. Exopod similar to male, but inner margin of first exopodal segment not as much concave; apical seta nearly 1.2 times as long as entire exopod.

Fifth leg (Figs. 2K, 3B) also simple cuticular plate, but with inner distal corner produced into strong and blunt spiniform process, which about 1.4 times as long as rest of leg, reaching in length tips of innermost seta; armature and ornamentation same as in male, except spinule at base of outermost seta (or very reduced setae) somewhat longer.

Sixth legs vestigial (Fig. 3B), narrowly fused into simple cuticular flap, covering gonopore, unornamented and unarmed; distal margin thin, medial part very short, lateral part longer and bilobate, each lobe terminating into more or less sharp tip. 


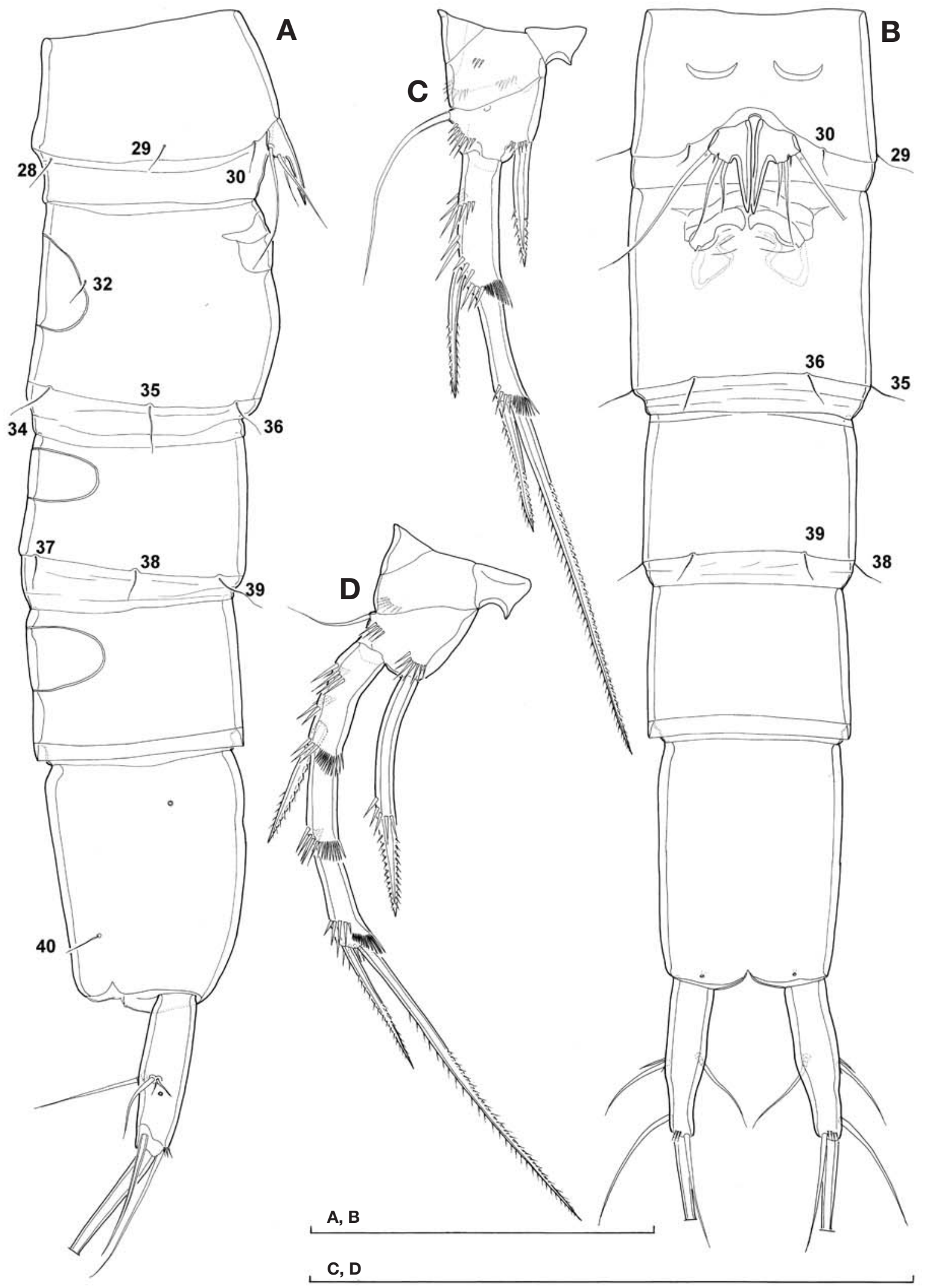

Fig. 3. Parastenocaris biwae Miura, 1969, female: A. urosome, lateral view. B. urosome, ventral view. C. third swimming leg, anterior view. D. fourth swimming leg, anterior view. Arabic numerals indicating pairs of sensilla homologous to those in male specimens. Scale bars $100 \mu \mathrm{m}$ for all. 
Remarks. This species is only known from the Lake Biwa drainage area in Japan, but it is rare there these days. Our repeated efforts to collect it from the lake's shore (including the type locality) failed, despite more than 30 samples taken in 2009 and 2010. As a part of the survey of subterranean biodiversity in the Lake Biwa drainage area, more than 100 samples were taken from 2008 to 2011, from caves, wells, river interstitial and lake interstitial, and the species was found in a single sample represented by three individuals. Specimens were obtained from the interstitial on the river banks, at the confluence of Daido and Seta rivers, from a mixture of medium size sand, gravel and large rocks. Relatively large size of this species suggests that it may prefer gravelly rather than sandy sediments.

\section{Parastenocaris koreana sp. nov. (Figs. 4-11)}

Synonymy. Parastenocaris brevipes Kessler: Lee and Chang, 2009: p. 176, fig. 6; Chang, 2009, p. 225, fig. 96; Chang, 2010, p. 91, fig. 41.

Type locality. South Korea, Gyeonggido region, Paju city, Jeokseong town, Imjin river, interstitial, $37^{\circ} 59^{\prime}$ $04.4^{\prime \prime} \mathrm{N} 126^{\circ} 55^{\prime} 41.2^{\prime \prime} \mathrm{E}$.

Specimens examined. Types: holotype male, paratype female and four paratypes (two males and two females) on one SEM stub (NIBRIV0000232646); three paratype males and two paratype females dissected on one slide each (NIBRIV0000232647-NIBRIV0000232651); one paratype male on one slide in toto (NIBRIV0000232652); 20 paratypes (eight males +12 females) together in $99 \%$ ethanol, sample No. 6(NIBRIV0000232653); another 15 paratypes (four males + seven females + four copepodids) together in $99 \%$ ethanol, sample No. 3 (NIBRIV000023 2654 ); another seven paratypes ( 3 males +4 females) together in 99\% ethanol, sample No. 3 (NIBRIV00002326 $55)$; and another six paratype males together in $99 \%$ ethanol, sample No. 5 (NIBRIV0000232656); all collected at type locality, 14 July 2010, leg. J.-L. Cho.

Other material: Three males and four males on one SEM stub (NIBRIV0000232654); 12 specimens (four males +3 females +5 copepodids) together in $99 \%$ ethanol, sample No. 4 (NIBRIV0000232657); another five specimens (two males + three females) together in $99 \%$ ethanol, sample No. 4 (NIBRIV0000232658); another male in 99\% ethanol, sample No. 17 (NIBRIV00002326 59); South Korea, Gyungsangbuk-do region, Uljin city, Geunnam town, Wangpi stream, interstitial from several beaches on banks, $36^{\circ} 57^{\prime} 41.4^{\prime \prime} \mathrm{N} 129^{\circ} 22^{\prime} 46.4^{\prime \prime} \mathrm{E}, 18$ May 2010, leg. J.-L. Cho.

Three males and three females on one SEM stub (NIB RIV0000232660); 10 specimens (three males +four fe- males + three copepodids) together in $99 \%$ ethanol, sample No. 12 (NIBRIV0000232657); and another 11 specimens (five males + three females + three copepodids) together in 99\% ethanol, sample No. 12 (NIBRIV000023 2657); South Korea, Gangwondo region, Pyeogchang city, Daehwa town, Daehwa stream, interstitial from beaches on banks, $37^{\circ} 29^{\prime} 17^{\prime \prime} \mathrm{N} 128^{\circ} 27^{\prime} 23^{\prime \prime} \mathrm{E}, 18$ May 2010 , leg. J.-L. Cho.

Etymology. The new species is named after Korea. The name should be treated as a Latin adjective, agreeing in gender with the feminine genus name.

Description. Male (based on holotype male, numerous paratypes and several specimens from two other localities). Total body length, measured from tip of rostrum to posterior margin of caudal rami (excluding caudal setae), from 395 to $49 \mu \mathrm{m}(437 \mu \mathrm{m}$ in holotype). Preserved specimen colourless. Nauplius eye absent. Body composed of prosome (consisting of cephalothorax and three free pedigerous somites (first pedigerous fused to cephalothorax)), and urosome (consisting of fifth pedigerous somite, genital somite, four abdominal somites, and caudal rami). Podoplean boundary between prosome and urosome inconspicuous. Habitus (Figs. 4A, 6A, F, 8A, 10A) cylindrical and very slender, without any demarcation between prosome and urosome; prosome/urosome ratio about 0.7 in dorsal view; greatest width in dorsal view at posterior end of cephalothorax but hard to establish (fourth pedigerous somites only slightly narrower); free prosomal somites in lateral view slightly narrower than cephalothorax or urosome. Body length/width ratio about 9.6; cephalothorax 1.07 times as wide as genital somite. Free pedigerous somites without any lateral or dorsal expansions, all connected by well developed arthrodial membranes. Hyaline fringes of all somites smooth, very narrow and hard to distinguish from arthroidal membranes (Fig. 4B), especially dorsally, except in preanal somite, where hyaline fringe well developed (Figs. 4A, 10A). Integument weakly sclerotized, smooth but covered with very shallow pits on all somites and caudal rami (sometimes hardly visible), ornamented only with sensilla and pores (no spinules, except on posterior margin of caudal rami ventrally), with round dorsal double cuticular window on cephalothorax (Figs. 8C, 10A), trapezoidal simple dorsal cuticular window on genital, and elongated simple dorsal windows on three postgenital somites (Fig. 10A). Pleural areas of cephalothorax and free pedigerous somites not well developed, cephalic appendages and coxae of swimming legs clearly exposed in lateral view (Figs. 6A, B, 8A).

Rostrum (Figs. 9A, 10A) small, membranous, not demarcated at base, ornamented with two large dorsal sensilla(No. 1), linguiform, not reaching distal margin of first antennular segment, about as long as wide.

Cephalothorax (Figs. 6B, 8C, 10A) about 1.8 times as long as wide in dorsal view; representing $19 \%$ of total 


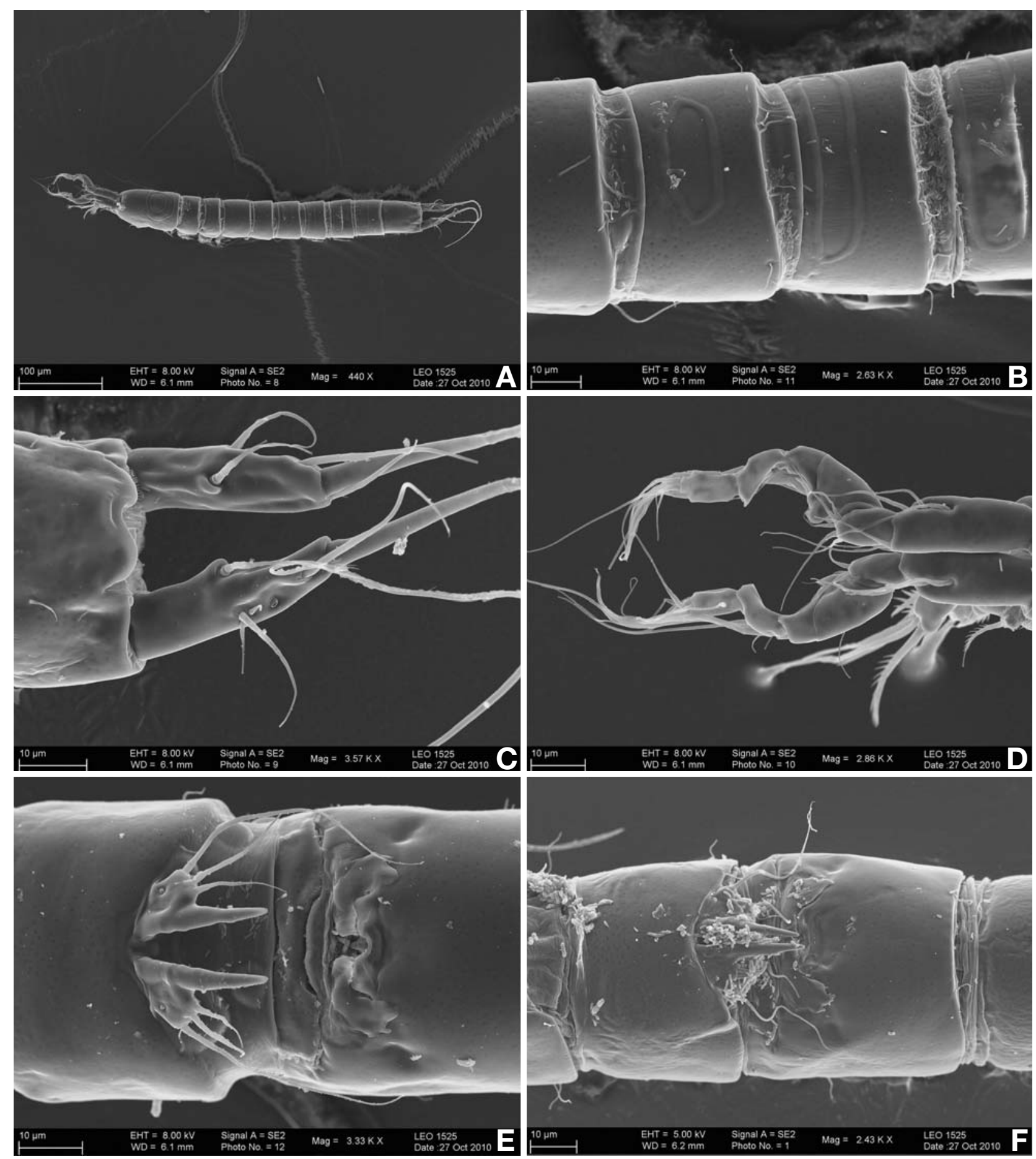

Fig. 4. Parastenocaris koreana sp. nov., Wangpi Stream, A-D. male 1. E. female 1. F. female 2: A. habitus, dorsal view. B. first four urosomites, dorsal view. C. anal somite and caudal rami, dorsal view. D. antennulae, dorsal view. E. fifth pedigerous and genital double somites. F. fifth pedigerous and genital double somites. Scale bars $100 \mu \mathrm{m}$ for A, $10 \mu \mathrm{m}$ for all others.

body length. Surface of cephalic shield ornamented with 16 pairs of large sensilla; with dense pattern of shallow cuticular pits of different sizes; five pairs of sensilla surround double cuticular window and its surface without pits; anterior lateral corners of outer window with short sutures pointing antero-laterally; pairs of sensilla Nos. $12-16$ belong to first pedigerous somite incorporated into cephalothorax. Athroidal membrane between cephalotho- 

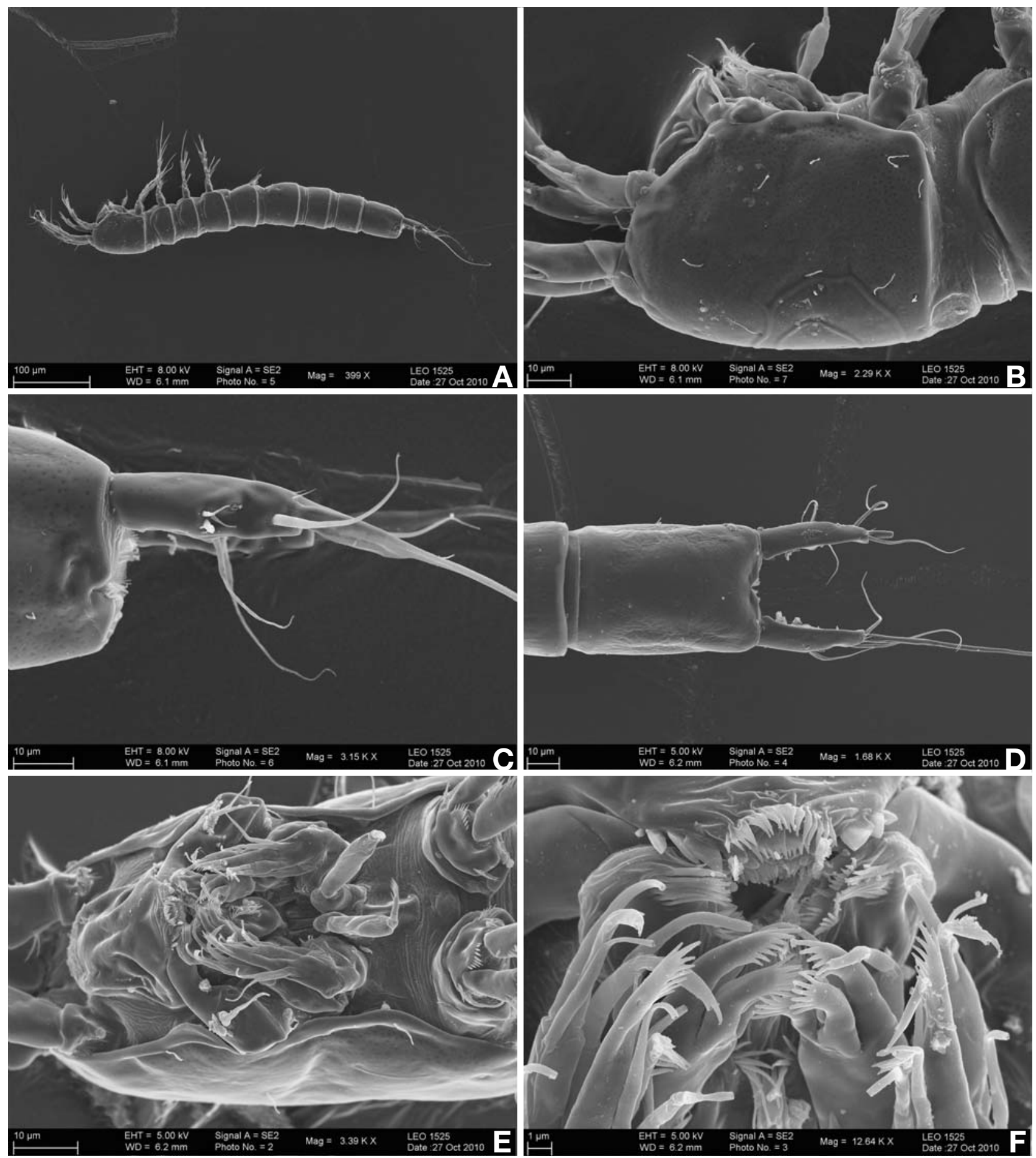

Fig. 5. Parastenocaris koreana sp. nov., Wangpi Stream, A-C. female 3. D. female 3. E and F. female 2: A. habitus, lateral view. B. cephalothorax, lateral view. C. anal somite and right caudal ramus, lateral view. D. anal somite and caudal rami, ventral view. E. mouth appendages, ventral view. F. mouth appendages, detail, ventral view. Scale bars $100 \mu \mathrm{m}$ for A, $10 \mu \mathrm{m}$ for B-E, $1 \mu \mathrm{m}$ for F.

rax and second pedigerous somite (first free) wider than between any other somites, with one large and many smaller folds and wrinkles.

Second pedigerous somite (=first free somite) (Figs. 6B,
$8 \mathrm{C}, 10 \mathrm{~A})$ slightly narrower than posterior half of cephalothorax in dorsal view, with four pairs of large sensilla (three dorsal and one lateral; Nos. 17-20; note lateral pair of sensilla No. 20 not visible in dorsal view in Fig. 10A), 


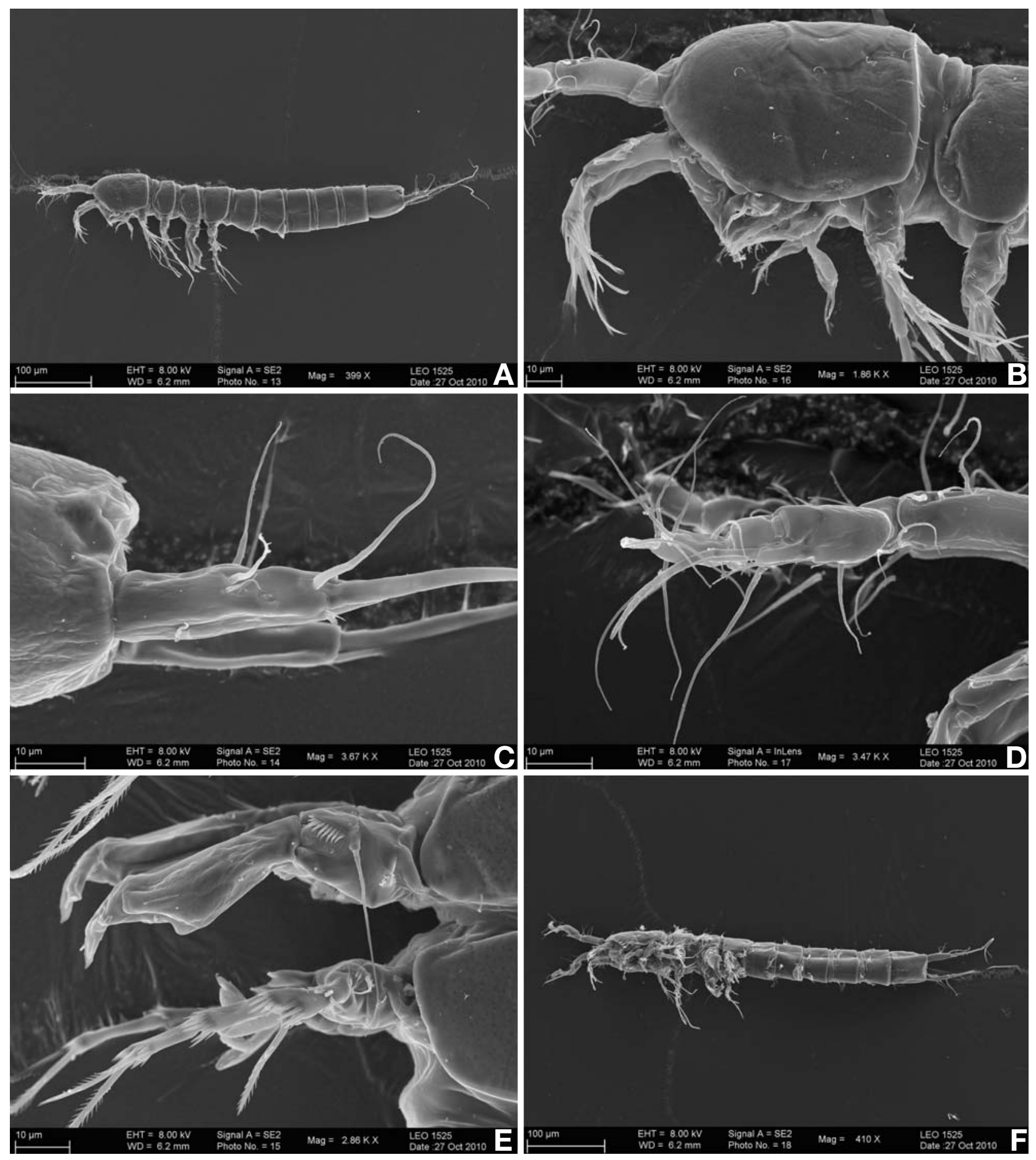

Fig. 6. Parastenocaris koreana sp. nov., Imjin River, A-E. holotype male. F. paratype male 1: A. habitus, lateral view. B. cephalothorax, lateral view. C. anal somite and left caudal ramus, lateral view. D. left antennula, lateral view. E. third and fourth swimming legs, lateral view. F. habitus, ventral view. Scale bars $100 \mu \mathrm{m}$ for A and F, $10 \mu \mathrm{m}$ for B-E.

and with small unpaired dorsal pore in anterior half. Postero-dorsal pair of sensilla (No. 18) serially homologous to pair No. 13 on first pedigerous somite, but for other pairs serial homology not that obvious.
Third pedigerous somite (Fig. 10A) slightly wider and shorter than second pedigerous, with four pairs of large sensilla (Nos. 21-24), also with unpaired dorsal pore. All sensilla serially homologous to those on second pediger- 

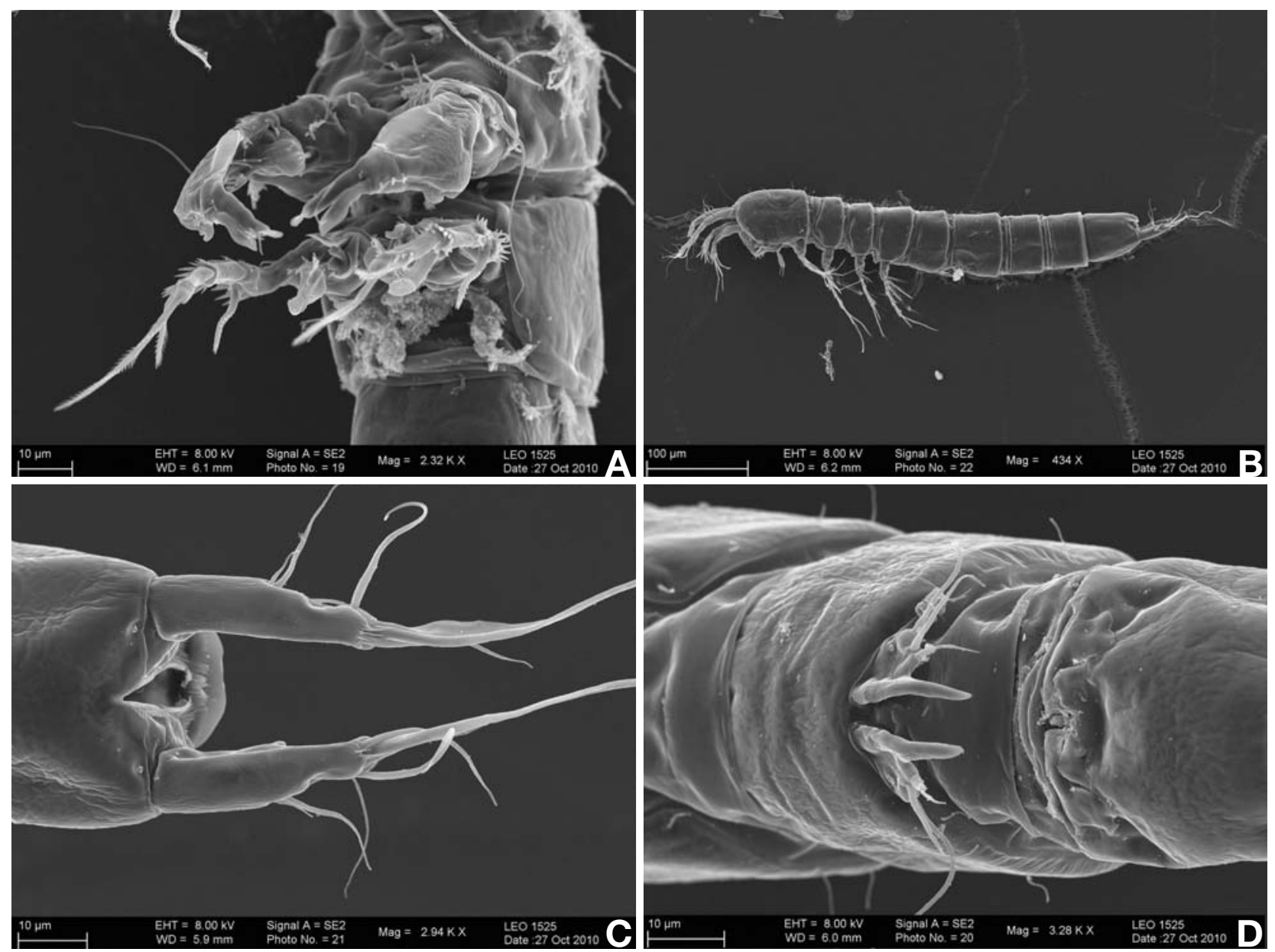

Fig. 7. Parastenocaris koreana sp. nov., Imjin River, A. paratype male 1. B. allotype female. C and D. paratype female 1: A. third and fourth swimming legs, ventral view. B. habitus, lateral view. C. anal somite and caudal rami, ventral view. D. fifth pedigerous and genital double somites. Scale bars $100 \mu \mathrm{m}$ for B, $10 \mu \mathrm{m}$ for all others.

ous somite (i.e. pairs Nos. 17 and 21, Nos. 18 and 22, Nos. 19 and 23, and Nos. 20 and 24); serial homology of dorsal cuticular pores between these two somites not that clear.

Fourth pedigerous somite (Fig. 10A) slightly narrower and considerably longer than third pedigerous somite in dorsal view, with only three pairs of large posterior sensilla (Nos. 25-27), with semicircular sutures in anterior part dorsally and unpaired cuticular pore in between them. Serial homology of sensilla between third and fourth pedigerous somites not that clear, except for lateral pairs (Nos. 24 and 27).

First urosomite (=fifth pedigerous somite) (Fig. 10A) slightly narrower and shorter than fourth pedigerous somite, also with three pairs of large posterior sensilla (Nos. 28-30), but without arched dorsal sutures or cuticular pores. All three pairs of sensilla serially homologous to those on fourth pedigerous somite (i.e. Nos. 25 and 28, Nos. 26 and 29, and Nos. 27 and 30; note: lateral pair of sensilla No. 30 not visible in dorsal view in Fig. 1A).

Second urosomite (= genital somite) (Fig. 10A, B) slightly wider and longer than first urosomite, about 1.1 times as wide as long in ventral view, with triangular small cuticular window in anterior half, also with three pairs of posterior sensilla (Nos. 31-33), but dorsal pair (No. 31) closer to each other than in first urosomite; single longitudinally placed spermatophore inside anterior half of somite about as long as somite. Dorsal pair of sensilla (No. 31) probably serially homologous to that on first urosomite (No. 28), but other two pairs probably not serially homologous.

Third urosomite (Figs. 4B, 10A) about as long and as wide as second urosomite, but with shorter and much wider dorsal cuticular window, also with three pairs of large posterior sensilla (Nos. 34-36).All sensilla probably serially homologous to those on second urosomite, but dorsal pair (No. 34) more widely spaced.

Fourth urosomite (Figs. 4B, 10A) with slightly larger 

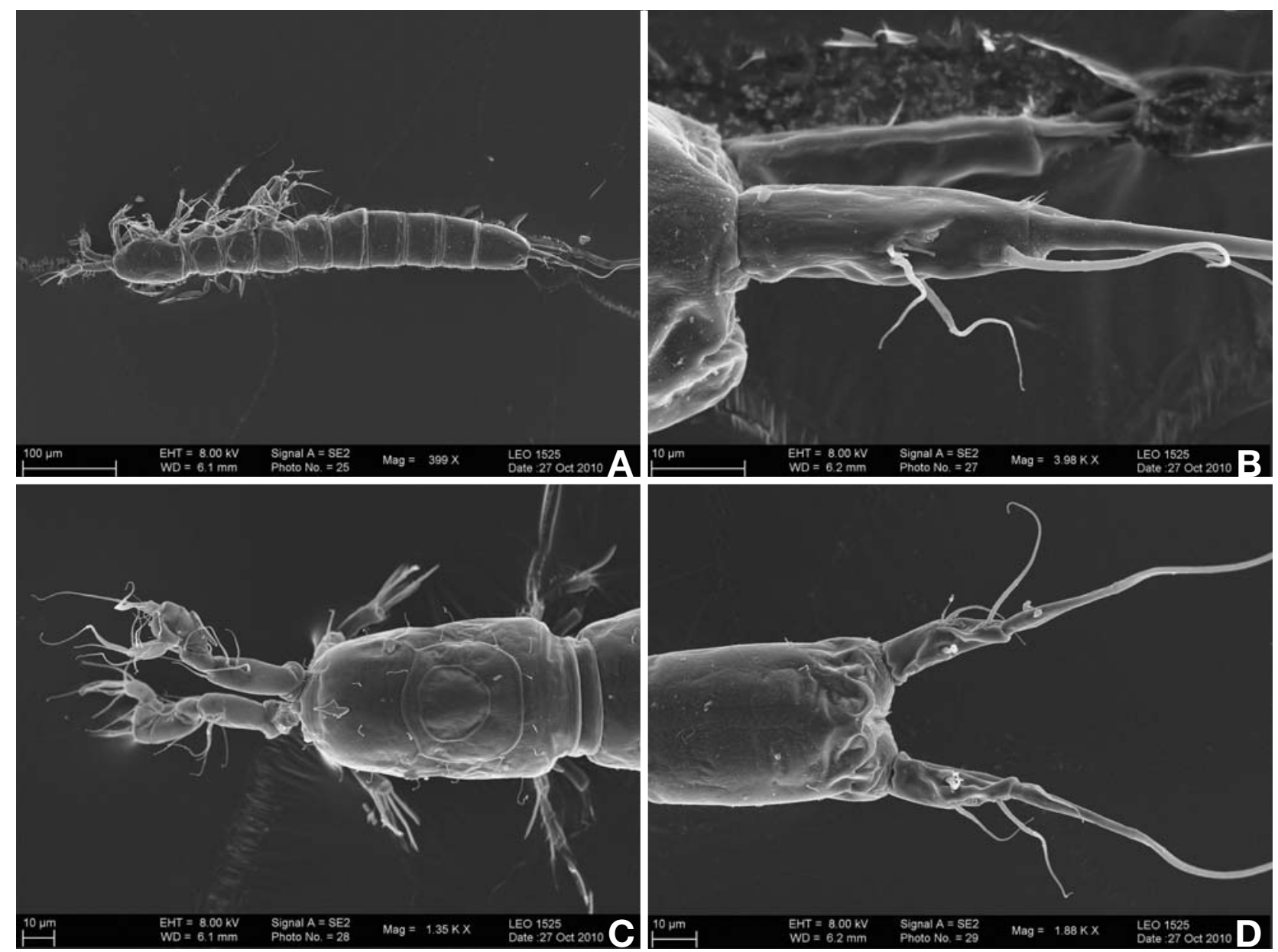

Fig. 8. Parastenocaris koreana sp. nov., Daehwa Stream, A and B. male 1. C and D. male 2: A. habitus, lateral view. B. anal somite and right caudal ramus, lateral view. C. cephalothorax and antennulae, dorsal view. D. anal somite and caudal rami, dorsal view. Scale bars 100 $\mu \mathrm{m}$ for $\mathrm{A}, 10 \mu \mathrm{m}$ for all others.

dorsal cuticular window and slightly longer, but as wide as and with similar ornamentation, consisting of only three pairs of large posterior sensilla (Nos. 37-39); all sensilla serially homologous to those on third usoromite.

Fifth urosomite (=preanal somite) (Figs. 4A, 6A, F, 8A, 10A) slightly narrower and shorter than fourth urosomite, with largest dorsal cuticular window of all urosomites, and without any surface ornamentation; hyaline fringe well defined on all sides.

Sixth urosomite (=anal somite) (Figs. 4C, 6C, 8D, 10A, C) about 1.4 times as long as and 0.9 times as wide as preanal somite, ornamented with pair of large dorsal sensilla at base of anal operculum (No. 40), pair of large lateral cuticular pores in anterior half, and pair of ventral pores at base of caudal rami (no spinules on ventral surface), in addition to numerous shallow cuticular pits. Anal operculum well developed, unornamented on outer surface, with smooth and deeply concave distal margin, not reaching posterior end of anal somite, representing $9 \%$ of somite's width. Anal sinus wide opened, ornamented with two long diagonal rows of slender spinules on ventral side, and one additional row on dorsal side (inner side of anal operculum).

Spermatophore (Figs. 10D) about 2.5 times as long as wide, kidney-shaped, with long and narrow, distally curved neck.

Caudal rami (Figs. 4C, 6C, 8B, D, 10A, C) slender, about 3.2 times as long as greatest width (ventral view) and about half as long as anal somite, cylindrical but tapering towards posterior end, slightly divergent, with space between them about 1.6 times of one ramus width; armed with seven elements (three lateral, one dorsal, and three apical). Ornamentation consists of large lateral cuticular pore at about $2 / 3$ of ramus length, and posterior ventral row of several spinules along posterior margin. Dorsal seta slender and smooth, inserted closer to inner margin at midlength, about 0.9 times as long as caudal ramus, triarticulate basally (inserted on two pseudo-joints). 

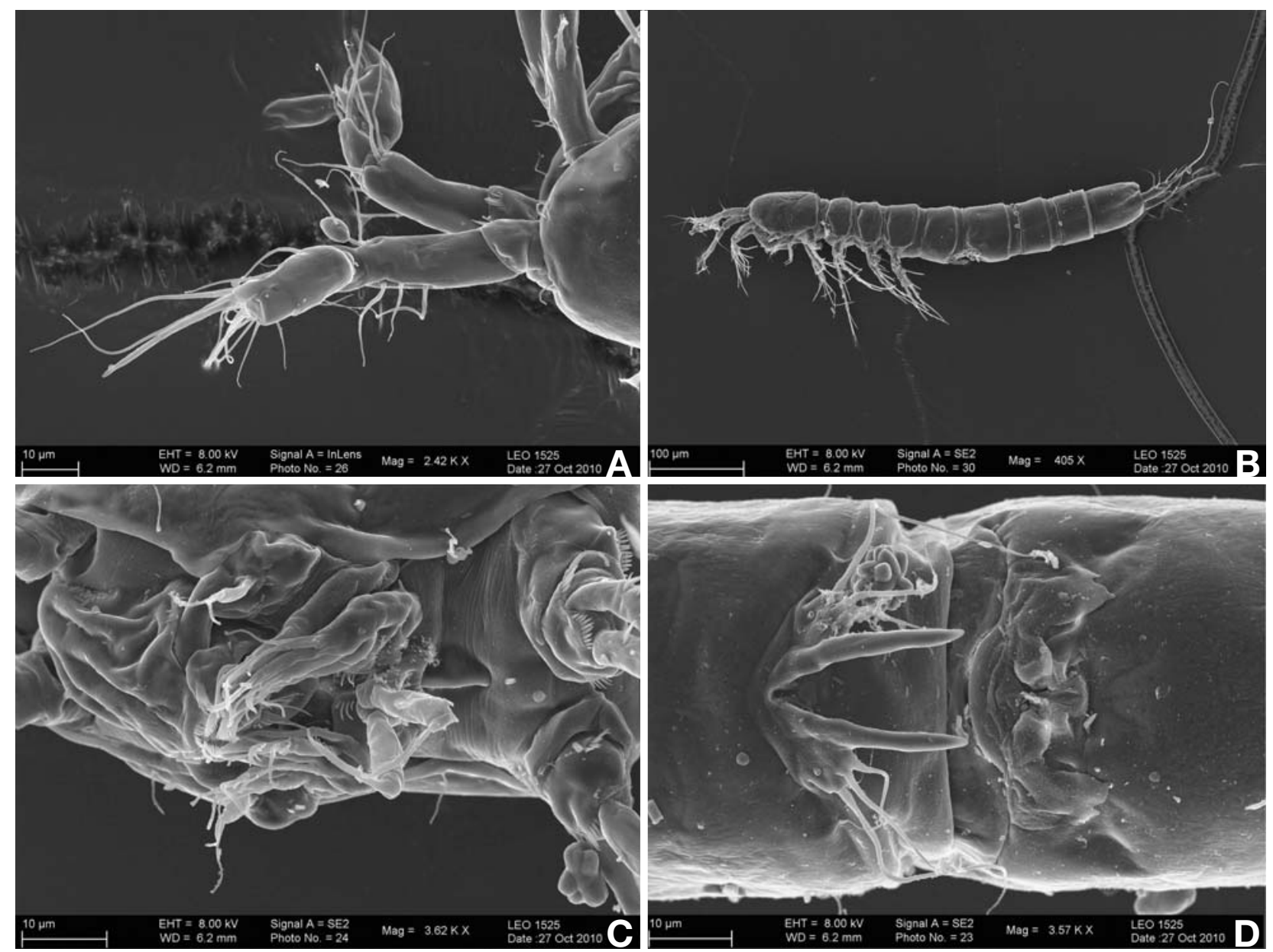

Fig. 9. Parastenocaris koreana sp. nov., Daehwa Stream, A. male 1. B. female 1. C. female 2. D. female 3: A. antennulae, lateral view. B. habitus, lateral view. C. mouth appendages, ventral view. D. fifth pedigerous and genital double somite. Scale bars $100 \mu \mathrm{m}$ for B, $10 \mu \mathrm{m}$ for all others.

Lateral setae slender and smooth, inserted very close to each other also at midlength, two larger ones more anteriorly and minute one in between and more posteriorly. Anterior lateral seta which inserted more dorsally longest, 0.7 times as long as ramus, 2.5 times as long as ventral anterior seta, and about five times as long as minute (distal) seta. Inner apical seta smooth, inserted close to ventral margin, about 0.8 times as long as ramus. Middle apical seta strongest, without breaking plane, smooth, about 3.6 times as long as ramus, pointing posteriorly but curled midlength. Outer apical seta also without breaking plane and smooth, relatively strong basally but much shorter, about 1.3 times as long as ramus, inserted close to dorsal surface and pointing latero-posteriorly.

Antennula (Figs. 4D, 6D, 8C, 9A, 10E) slightly shorter than cephalothorax, slender, eight-segmented, prehensile and strongly digeniculate, ornamented with arched row of ventral spinules on first segment distally, and with ribbed elongated chitinous plate on anterior surface of sixth segment. First segment very short, while second longest. Geniculation between third and fourth and between sixth and seventh segments; last two segments at $90^{\circ}$ angle. Distal anterior corner of seventh segment produced into very small spiniform process, but larger proximal spiniform process present on fifth segment on anterior surface. Long aesthetasc on fifth segment reaching beyond tip of appendage for length of last segment, fused basally to slightly longer seta, relatively slender and blunt distally; much shorter and more slender apical aesthetasc on seventh segment, fused basally to two setae (acrotheck). Setal formula: 0.6.4.2.4.0.1.9. All setae slender and all, except largest seta on second segment, smooth; most setae with pore on tip; proximalmost seta on second segment unipinnate with several long spinules along anterior surface, much shorter than two large setae on fifth segment or longest apical seta on eighth segment (latter probably longest); only seta on eighth segment minute.

Antenna (Figs. 6B, 9A, 10F) relatively stout and short, 




Fig. 10. Parastenocaris koreana sp. nov., Imjin River, paratype male 2: A. habitus dorsal view. B. genital somite, ventral view. C. anal somite and caudal rami, dorsal view. D. spermatophore. E. antennula, ventral view. F. exopod of antenna. G. endopod of second swimming leg, anterior view. H. third swimming leg, anterior view (undissected). I. third swimming leg, posterior view. J. tip of third swimming leg, posterior view. K. fourth swimming leg without last two exopodal segments, posterior view. Arrows indicating features different from $P$. biwae Miura, 1969. Arabic numerals indicating pairs of sensilla numbered consecutively from anterior to posterior part of the body and from dorsal to ventral side. Scale bars $100 \mu \mathrm{m}$ for all. 
composed of coxa, allobasis, one-segmented endopod, and one-segmented exopod. Coxa very short, unarmed, ornamented with three short spinules. Allobasis about three times as long as wide, unarmed but ornamented with two rows of large spinules on anterior surface. Endopod 0.8 times as long as allobasis and nearly three times as long as wide, with two parallel surface frills subdistally, ornamented with large spinules along anterior surface, armed laterally with two short spines (proximal one shorter) and apically with five strong elements (two geniculate). Exopod minute, cylindrical, about twice as long as wide, unornamented but armed with single apical seta, which 2.6 times as long as segment. All antennal armature unipinnate.

Labrum (Fig. 6B) large and triangular in lateral view, with narrow and straight cutting edge, without any ornamentation on anterior surface, with several parallel rows of spinules along narrow cutting edge (three on outer distal corners strongest and very wide).

Paragnaths (Fig. 6B, F) strongly fused into trilobite structure, with numerous distal rows of slender short spinules on lateral lobes, one distal row of minute spinules on central lobe, and another transverse row of 14 very long spinules on posterior surface of central lobe at about $2 / 3$ of its length.

Mandibula (Fig. 6B) with narrow cutting edge on elongated coxa, armed with one complex tooth ventrally, one unipinnate seta dorsally, and several smaller teeth and/ or spinules in between. Palp one-segmented, cylindrical, about 2.5 times as long as wide, unornamented, and armed apically with two smooth and subequal setae, each with pore on tip.

Maxillula (Fig. 6B) with relatively large praecoxa, arthrite rectangular, about 1.5 times as long as wide from lateral view, ornamented with single spinule on posterior surface near dorsal margin, armed with lateral strong seta and four apical elements (probably three spines and one strong seta; apical spines with crown of spinules on tip, resembling small hands). Coxal endite armed with one smooth seta apically. Basis slightly longer than coxal endite, armed with three apical setae (two smooth and slender, one curved and unipinnate), and single minute lateral seta. Endopod and exopod absent (fused to basis without trace), minute seta on basis probably representing remnants of exopodal armature. All coxal and basal setae, as well as smooth lateral seta on praecoxa, with pore on tip.

Maxilla (Fig. 6B) composed of syncoxa, basis, and one -segmented endopod, ornamented with row of five spinules on inner side of syncoxa proximally, and with arched row of six spinules on posterior side of syncoxa close to outer margin. Syncoxa with two endites, basal armed with single smooth seta apically, distal armed with two smooth and one pinnate seta apically. Basis drawn out into strong and unipinnate claw, without seta at base, with cuticular pore on convex margin near distal tip. Endopod represented by minute segment, armed with two smooth subequal apical setae. All setae on maxilla with pore on tip.

Maxilliped (Fig. 6B) with short and relatively strong syncoxa, unarmed and unornamented; basis slender, almost five times as long as wide and three times as long as syncoxa, unornamented and unarmed; endopod represented by short curved claw, swollen at base as indication of ancestral one-segmented endopod, ornamented with several strong spinules along concave margin distally, about 0.7 times as long as basis.

First swimming leg (Figs. 6B, F, 8A) with unarmed praecoxa, coxa, and intercoxal sclerite. Intercoxal sclerite very small, with narrow and concave distal margin and smooth. Paecoxa ornamented with several rows of minute spinules on anterior surface. Coxa with posterior row of large spinules on posterior surface and close to outer margin. Basis somewhat shorter than coxa, pentagonal, ornamented with bunch of large spinules on outer margin, another bunch along distal margin at base of endopod, and several long spinules on inner margin proximally; armed with single short seta on outer margin. Exopod three-segmented, armed with one outer spine on first segment and four elements on third segment (two outer spines and two apical geniculate setae); ornamented with few large spinules along outer margin and distally on all segments. Endopod two-segmented, about as long as exopod; first segment reaching slightly beyond distal margin of second exopodal segment, about four times as long as wide, unarmed, ornamented with two short rows of large spinules on outer margin, one longer row of even longer spinules on inner margin, and three spinules on anterior surface along distal margin; second segment armed apically with long geniculate seta and much shorter spine; endopodal geniculate seta 1.3 times as long as entire endopod, 1.2 times as long as larger geniculate exopodal seta, and twice as long as outer spine on endopod. All exopodal and endopodal armature unipinate along outer margin.

Second swimming leg (Figs. 6B, F, 8A, 10G) with smooth praecoxa and intercoxal sclerite. Intercoxal sclerite large, trapezoidal, with deeply concave distal margin. Praecoxa triangular and large. Coxa short, rhomboidal, with diagonal row of small spinules on anterior surface and two shorter rows of spinules along distal margin on posterior surface. Basis larger than coxa, semicircular, unarmed, ornamented with row of spinules on outer margin and another arched row of spinules at base of endopod. Exopod three-segmented, ornamented with large spinules along outer margin, and with distal hyaline frills on each segment on inner side; first segment armed with single outer spine; second segment unarmed; third segment armed with three long elements (probably outer 


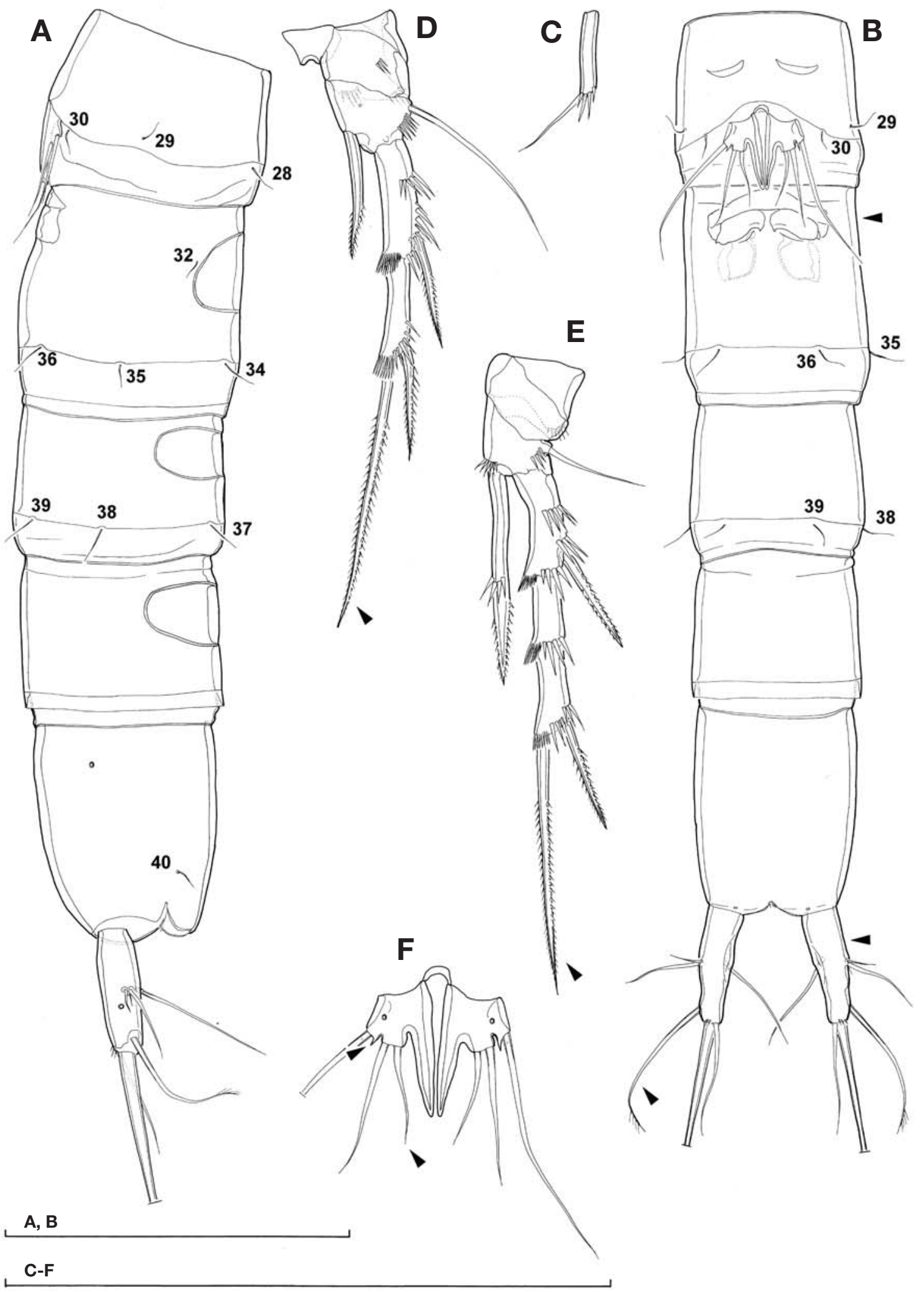

Fig. 11. Parastenocaris koreana sp. nov., Imjin River, paratype female 2: A. urosome, lateral view. B. urosome, ventral view. C. endopod of second swimming leg, anterior view. D. third swimming leg, anterior view. E. fourth swimming leg, anterior view. F. fifth legs, anterior view. Arrows indicating features different from P. biwae Miura, 1969. Arabic numerals indicating pairs of sensilla homologous to those in male specimens. Scale bars $100 \mu \mathrm{m}$ for all. 
spine and two apical setae), innermost element 1.3 times as long as entire exopod; all exopodal armature bipinnate. Endopod one-segmented, cylindrical and slender, 5.8 times as long as wide, reaching 3/4 of first exopodal segment in length, ornamented with three large spinules along apical margin; armed apically with single smooth seta, which about 0.8 times as long as segment and pointing inwards.

Third swimming leg (Figs. 6E, 7A, 10H-J) with smooth intercoxal sclerite, which largest of all legs, trapezoidal, and with short and concave distal margin. Praecoxa not well defined on anterior surface, triangular on posterior surface, about as large as in second leg, unarmed and unornamented. Coxa rectangular, with arched row of large spinules on anterior surface, and two rows of spinules along posterior margin on posterior surface (outer minute). Basis robust, ornamented with long row of large spinules and one pore on anterior surface, armed with outer long and slender seta; distal inner corner of basis produced distally as bulbous soft semicircular lobe, smaller than in $P$. biwae. Endopod represented with single smooth and minute armature element, inserted on inner margin at 3/4 of basis length, shorter but stronger than spinules on anterior surface. Exopod with both segments fused; ancestral proximal segment 2.7 times as long as wide, curved inwards and with thin hyaline lamella along inner margin, and three strong and short chitinous beaks on posterior surface, ornamented with two or three minute spinules on distal outer corner; armed subapically with simple, strong, smooth and inwardly curved spine, which about as long as apophysis and more or less flat distally; ancestral distal segment (apophysis) cylindrical, oriented slightly inwards, ornamented with single pore on anterior surface; armed with single short element on top, which leaf-like, with very thin cuticulum, more or less ovoid.

Fourth swimming leg (Figs. 6E, 7A, 10K) with smooth praecoxa and intercoxal sclerite. Intercoxal sclerite shorter and smaller than in third, with equally long and concave distal margin. Pracoxa small and triangular. Coxa rhomboidal, slightly larger than in second leg, unarmed, ornamented with short distal row of minute spinules on posterior surface. Basis large and more or less rectangular, armed with single smooth outer seta, ornamented with two minute spinules on outer margin at base of outer seta, and with three huge chitinous spiniform process on inner distal corner; anterior process bilobate distally and very wide; inner process spiniform and curved outward, longest; posterior process shortest but most strongly chitinized. Exopod three-segmented, ornamented with few large spinules along outer margin on all segments, and with hyaline frills distally on inner side; first segment with strongly concave and smooth inner margin, armed with single outer spine; second segment unarmed; third segment armed with outer spine and long and strong apical seta; apical seta about as long as entire exopod, and more than twice as long as outer spine. Endopod onesegmented, narrower but longer than first exopodal segment, cylindrical proximally and bilobate distally, with inner lobe somewhat longer and stronger, ornamented with several strong spinules (although not as long as in $P$. biwae); inner lobe with thin cuticulum and with several minute spinules along distal margin.

Fifth leg (Fig. 6F) simple short cuticular plate, almost rectangular in shape, ornamented with single pore on anterior surface and single spinule at base of outermost seta, armed with three smooth setae; outermost seta (ancestral basal one) longest, almost three times as long as entire leg; middle seta (probably ancestral outer endopodal) much shorter, 1.5 times as long as leg, and 1.3 times as long as innermost seta (inner endopodal). Fifth legs distinct at base, with small space between them, pointing caudally, not reaching distal margin of fifth pedigerous somite.

Sixth legs (Fig. 10B) smooth, unarmed and unornamented, forming simple large operculum covering gonopore, probably both fused together or right one reduced and left one enlarged, representing $62 \%$ of somite's width.

Female (based on allotype female, many paratypes and several specimens from two other localities): Body length, excluding caudal setae, from 403 to $443 \mu \mathrm{m}(432 \mu \mathrm{m}$ in allotype). Habitus (Figs. 5A, 7B, 9B), ornamentation of prosomites, colour and nauplius eye similar to male, except genital and first abdominal somite fused into double somite and habitus slightly less slender.

Genital double somite (Figs. 4E, F, 7D, 9D, 11A, B) about 1.2 times as long as wide (ventral view), without any trace of subdivision, with oval dorsal cuticular window in anterior half, which much larger than that in male (originating from fused windows of two ancestral somites). Genital complex occupying anterior ventral half of genital double somite; genital apertures covered by vestigial sixth legs; median copulatory pores also partly covered by fused sixth legs; seminal receptacles small, ovoid, with strongly sclerotized outer wall and weakly sclerotized other walls; copulatory duct very short and weakly sclerotized. All posterior sensilla homologous to those on male third urosomite, while all sensilla from male second urosomite missing except lateral pair (No. 32).

Third, fourth (preanal), and fifth (anal) urosomites very similar to male (Figs. 5A, D, 7B, C, 9B, 10A, B).

Caudal rami (Figs. 5C, D, 7C, 10A, B) slightly shorter in proportion to anal somite, about three times as long as wide in ventral (or dorsal) view, and slightly less divergent, but also cylindrical and armed and ornamented as in male.

Antennula (Figs. 5A, B, 7B) seven-segmented, ornamented on first segment with few minute spinules on ven- 




Fig. 12. One of six equally parsimonious cladograms resulting from the analysis of 38 morphological characters (Table 1 ), scored for 20 species of the brevipes group of the genus Parastenocaris Kessler, 1913 and three outgroups: Proserpinicaris young Karanovic, Cho and Lee, 2012; Dussartstenocaris idioxenos Karanovic and Cooper 2011; and Kinnecaris lakewayi Karanovic and Cooper, 2011. All unsupported nodes hard collapsed. Full circles, presumed synapomorphies; empty circles, presumed plesiomorphies or homoplasies; numbers above branches, characters; numbers below branches, character states. See text for further explanation.

tral surface, not geniculate, with slender aesthetasc on fourth segment, not reaching beyond tip of appendage, and more slender apical aesthetasc on seventh segment, which fused basally to two apical setae; proximal aesthetasc much more slender than in male; setal formula: 0.4.5.2.1.0.9. All setae, except proximalmost one on second segment, smooth, and most setae with pore on tip.

Antenna (Fig. 9B), labrum (Figs. 5E, F, 9C), paragnaths (Figs. 5E, F, 9C), mandibula (Figs. 5E, F, 9C), maxillula (Figs. 5E, F, 9C), maxilla (Figs. 5E, F, 9C), maxilliped
(Figs. 5E, 9C), first swimming leg (Figs. 5A, B, E, 7B, 9B, C), and second swimming leg (Figs. 5A, 7B, 9B, 11C) very similar to those in male.

Second swimming leg (Fig. 11C) with slightly proportionately less elongated endopod.

Third swimming leg (Fig. 11D) with smooth praecoxa and intercoxal sclerite. Coxa with three large spinules on anterior surface, and two rows of spinules along distal margin on posterior surface, unarmed. Basis ornamented with several large spinules on outer margin distally, arm- 
ed with very long and smooth outer seta, which 0.9 times as long as entire exopod. Exopod two-segmented, ornamented with large spinules along outer margin, both segments with hyaline frills distally on inner side; first segment armed with single outer spine; second with outer spine and apical strong seta; all elements bipinnate; apical seta 1.3 times as long as entire exopod. Endopod one -segmented, small, cylindrical and unornamented, armed with apical spiniform bipinnate element on tip, which basally fused to segment, reaching posterior margin of first exopodal segment in length.

Fourth swimming leg (Fig. 11E) without spiniform processes on basis, with row of spinules at base of endopod. Endopod one-segmented, slender and long, cylindrical, straight, ornamented with apical row of four large spinules at base of apical spine (no lateral spinules on inner margin); apical spine not distinct at base, bipinnate and robust, and about 0.9 times as long as endopod; endopod with apical spine reaching midlength of third exopodal segment in length. Exopod similar to male, but inner margin of first exopodal segment not as much concave; apical seta as long as entire exopod.

Fifth leg (Figs. 4E, F, 7D, 9D, 11F) also simple cuticular plate, but with inner distal corner produced into strong and blunt spiniform process, which about 1.2 times as long as rest of leg (proportionately shorter than in $P$. biwae), not reaching in length tips of innermost seta; armature and ornamentation same as in male; spinule at base of outermost seta smaller than in P. biwae.

Sixth legs vestigial (Figs. 4E, F, 7D, 9D, 11B), narrowly fused into simple cuticular flap, covering gonopore, unornamented and unarmed; distal margin thin, medial part very short, lateral part longer and bilobate, each lobe terminating into more or less sharp tip, but shape and length of lobes and apical tips variable.

Remarks. This species seems to be widely distributed in Korea. Lee and Chang (2009) and Chang (2009; 2010) reported it (as $P$. brevipes) from seven different localities. We add three new localities here. Specimens were obtained only from interstitial on river banks, and no records from caves, wells or other subterranean habitats exist. The species has never been recorded in surface water habitats, so it is probably an obligate subterranean water dweller (stygobiont).

\section{Discussion}

Reid (1995) examined some specimens of $P$. biwae and synonymized it with the widely distributed $P$. brevipes, although she noted that "... specimens from Lake Biwa, Japan, presented a series of consistent differences from most other populations examined". Other populations examined were either from northern Europe or North
America. She especially pointed out the reduced and spiniform endopod of the third leg in male (as opposed to a slender and long seta in non-Asian populations). Chang (2009; 2010) reported $P$. brevipes for the first time from Korea, providing a limited set of drawings. Our examinations of both Korean and Japanese populations indicated them to be distinct species (although closely related), differing in a number of morphological characters. Three possible hypotheses emerged: either we are dealing with three different species, or one of the Asian populations is conspecific with $P$. brevipes. As both Korean and Japanese specimens have the same shape and size of the third leg endopod in male, it is most probable that they shared an immediate common ancestor. And, because they are distinct species, we are most probably dealing with three different species. Thus we reinstated $P$. biwae as a valid species, and described the Korean population as a new species.

Parastenocaris koreana is unquestionably very closely related to $P$. biwae, in so much so that they form a sister species pair. Both are also closely related to the widely distributed $P$. brevipes, but can be distinguished by the very small and spiniform endopod of the third leg in male, more inwardly curved posterior part of the caudal rami, more pronounced dorsal ridge on the caudal rami and longer dorsal caudal seta, very large and bilobate anterior chitinous process on the fourth leg basis in male, as well as wide and long outer endopodal lobe on the male fourth leg. However, even after we exclude the Korean population from $P$. brevipes and reinstate $P$. biwae as a valid species, there is very little doubt that the widely distributed European/North American P. brevipes, as redefined by Reid (1995), represents a complex of several closely related species. This is quite obvious now from the variations in the shape and size of the chitinous processes on the fourth leg basis in male, variations in relative length and proportions of the male sixth leg armature, as well as variations in the size of the inner-distal chitinous process on the female fifth leg (as illustrated by Reid, 1995: Figs. 3, 4). This hypothesis, however, will need further investigation to be properly assessed. We especially refer here to the necessity for use of microcharacters (morphological characters associated with fine ornamentation of somites and appendages) and molecular characters. Combined morphological and molecular studies have shown recently a potential for short range endemism in this group of subterranean harpacticoids, with very little interspecific variability (Karanovic and Cooper, 2011a).

Differences between $P$. koreana and $P$. biwae are relatively settled but numerous, and many of them are arrowed in Figs. 10 and 11. Parastenocaris koreana is a much smaller species (note that Figs. 1A and 10A are drawn to the same scale), with shorter caudal rami (proportionately to the anal somite), differently shaped anal operculum 
(concave versus convex), more elongated genital double somite in female, shorter inner distal process on the female sixth leg, as well as proportionately shorter apical setae of the second, third, and fourth legs exopods in both sexes.

Detailed examinations of the three disjunct populations of $P$. koreana presented above revealed also some geographical variation, especially in the surface ornamentation of somites (i.e. smoothness and presence and frequency of cuticular pits; see Figs. 4-9), which may indicate some population structuring (for example indicative of different subspecies) or even cryptic speciation. However, despite detailed analyses we were not able to find any additional and reliable morphological differences between these three populations. Similarly disjunct localities in Korea produced three short range endemics in the genus Proserpinicaris Jakobi, 1972, but with significant and reliable morphological differences between species (Karanovic et al., 2012). This would either suggest a different age for colonization of subterranean habitats for these two genera in Korea, or different evolutionary rates as inferred from their morphology. Unfortunately, all Korean samples were preserved and stored in ethanol of less than $80 \%$, and our attempts to PCR amplify the COI gene have failed. Remarkable similarities between our drawings and those of Lee and Chang (2009) (repeated in Chang, 2009; 2010), down to minute details in proportions of armature elements on the female swimming legs, are additional indications that we are dealing with a morphologically conservative population in Korea.

Our examination of the sensilla and pore pattern in $P$. koreana and $P$. biwae, showed all male specimens to be ornamented with exactly 40 pairs of sensilla (see Figs. 1 and 10), while females have two pairs reduced (Nos. 31 and 33) at the fusion of the genital and first abdominal somites (Figs. 3 and 11). These characters were not studied in harpacticoid copepods in the past, mostly because of the quality of optical instruments available (these are minute structures) but also because they were considered very variable. Karanovic et al. (2012) showed that these structures are relatively conservative characters, without any variability between three closely related short range endemics from the genus Proserpinicaris. In this paper we show this to be the case also between two closely related species from the genus Parastenocaris. Most sensilla could be recognised as homologous between these two genera according to their position, and some can be also recognised as serially homologous, which is a novel discovery for harpacticoid copepods. Most interestingly, the two genera differ in the number of sensilla (45 vs. 40 ), with most of the differences observed on the third and fourth urosomites. This suggests that sensilla number and pattern may be also phylogenetically informative characters, and we included some in our cladistics analysis, de- spite the fact that they are described only in a few species. Karanovic and Cooper(2011a) demonstrated recently using molecular tools that fine ornamentation of somites with spinules can be used to separate closely related species in the genus Kinnecaris, and we speculate here that phylogenetical relationships between different parastenocaridid genera may be inferred from ornamentation of somites with sensilla. This, however, would need to be studied in a larger group of species and genera.

Our cladistic analysis resulted in six equally parsimonious trees (Fig. 12), with a length of 107 steps, a consistency index $(\mathrm{Ci})$ of 38 , and a retention index (Ri) of 54 . The values of the $\mathrm{Ci}$ and $\mathrm{Ri}$ indices indicate a very high proportion of convergences (homoplastic changes). This is obviously a result of the choice of characters, as well as missing characters in many species due to incomplete descriptions, but it also reflects a general pattern: copepod groups with a high proportion of subterranean species display and unusually high proportion of convergences (Karanovic and Hancock, 2009; Karanovic and Abe, 2010; Karanovic et al., 2011; Karanovic and Cooper, 2011a; 2011b). The $\mathrm{Ci}$ and $\mathrm{Ri}$ indices did not change when we analysed all characters unweighted, although the number of steps increased to 112 . Naturally, the tree topology did not change with mopping the two uninformative characters (Nos. 3 and 8). The choice of characters was limited by the lack of females in three species (P. brincki, P. lanceolata, and $P$. singhalensis), only available species descriptions severely lacking in detail in nine species (P. brincki, P. feuerborni, P. hinumaensis, P. irenae, $P$. lanceolata, $P$. longipoda, $P$. noodti, P. oshimaensis, and $P$. singhalensis), and also very conservative nature of many morphological characters in this harpacticoid family. In fact many morphological characters that show interspecific variability, and sometimes even intraspecific variability, in other harpacticoid families are extremely conservative even in different, and not very closely related, parastenocaridid genera. Karanovic and Cooper (2011b) showed, for example, that divergences in mtCOI DNA between three Australian parastenocaridid genera (Parastenocaris, Kinnecaris, and Dussartstenocaris) are remarkably similar in value to those between three canthocamptid genera, despite all parastenocaridid genera having the same armature formula of the swimming legs. This conservative morphology was one of the reasons many species were originally described after a limited set of morphological characters, with very little attention being paid to somite ornamentation or other microcharacters. As a consequence of a very diminutive size of parastenocaridids, even features that were described and illustrated were seldom studied in detail and have to be re-interpreted with caution. These all explain why 16 morphological characters $(41 \%)$ in our analysis were scored for the male third and fourth legs alone, which 
are sexually dimorphic features in this family.

Nevertheless, the ingroup was well defined in all our analyses by at least three synapomorphies (Characters 27, 28 and 29), all of them related to the position and nature of spiniform transformations on the male fourth leg basis. Not surprisingly $K$. lakewayi is much more closely related to the brevipes group than are two other outgroups. The genus Kinnecaris belongs to the nominotypical subfamily, just as the genus Parastenocaris, while Proserpinicaris belongs to the subfamily Fontinalicarididae Schminke, 2010 (see Schminke, 2010; Karanovic and Cooper, 2011a; Karanovic et al., 2012). The subfamilial position of the genus Dussartstenocaris is not quite clear (see Karanovic and Cooper, 2011b), but our present analysis shows it to be more closely related to Proserpinicaris than to Kinnecaris or the brevipes group of Parastenocaris, so we would suggest to provisionally place Dussartstenocaris in Fontinalicarididae, until major subfamily groups are well defined by synapomorphic features.

Two Japanese species, $P$. hinumaensis and $P$. oshimanesis, cluster together in all our analyses, but they would have to be redescribed before their phylogenetic relationships could be discussed with more confidence. For example, they were both reported with dorsal spinules on the anal operculum, but it is quite possible that authors misinterpreted slender spinules on the ventral (internal) side, which are common in many harpacticoids and were illustrated with SEM photographs for a number of parastenocaridid species by Karanovic (2006), Karanovic and Cooper (2011a), and Karanovic et al. (2012), and are also clearly visible in the newly described Korean species (see Fig. 7C).

Surprisingly, all analyses suggest the Australian $P$. jane as a sister clade to all other species of the brevipes group, and not at all closely related to another Australian species, $P$. kimberleyensis, the latter being most closely related to the Sumatran P. feuerborni. This result suggests that Reid (1995) probably underestimated vicariance, when she speculated that the brevipes group probably originated somewhere in South East Asia, and that the present distribution of this group could be a combination of both ancient vicariance and subsequent dispersal. As it stands now, the center of diversity of this group is in India (including Sri Lanka), and two Indian species ( $P$. savita and $P$. gayatri) also show basal positions on our tree. It is quite possible that the group originated somewhere in the Gondwanaland in the rift valley between India and Western Australia, just before the separation of the Indian plate. One branch could have colonised East Asia after the contact of the Indian plate with Laureasia, and then proceeded to colonise Northern Europe and North America from there. A very close relationship between the North East Asian species (P. biwae and P. kore- ana) and North European and North American widely distributed $P$. brevipes would suggest a relatively recent invasion, and absence of this group in subterranean waters in Southern Europe suggests it probably did not survive last glacial maxima in European refuges but probably colonised recently somewhere from Asia. The ability of $P$. brevipes to at least survive in surface environments, such as Sphagnum bogs, can explain a very wide distribution of this branch in the Northern Hemisphere. Reid (1995) speculated that they may be passively dispersed by migrating birds. If the brevipes group originated (at least partly) in India, it would be easy to imagine its gradual active upstream invasion of the newly formed Himalayan rivers, and gradual adaptations to colder temperatures at high altitudes. Such forms would be preadapted to colonise waters of North East Asia in the post-glacial periods during the Quaternary. We speculate that the ability of $P$. brevipes to colonise Sphagnum bogs has evolved relatively recently, perhaps because of the lack of competition and also unavailability of interstitial environments at high altitudes and latitudes.

Reid (1995) hesitated to include the North American P. palmerae in the brevipes group. Our cladistic analysis suggests this species to be deeply nested in the brevipes group, which supports its placement here, as proposed by Karanovic (2005a; 2006). It clusters together with the above mentioned brevipes/biwae/koreana clade (the first species being also known from North America), and one Indian species $(P$. gundlakamma). However, the group is not supported by a single clear synapomorphy and would have to be tested by molecular phylogenies.

The terminal clade in our analysis is well defined by two synapomorphies (Characters 22 and 24), and includes seven species from India and Sri Lanka (P. brincki, $P$. irenae, $P$. lanceolata, $P$. muvattupuzha, $P$. noodti, and $P$. sultej), one species from South East China (P. longipoda) and two Japanese species ( $P$. hinumaensis and $P$. oshimaensis). However, the relationships within the group are quite problematical and strict consensus (not presented) of all seven trees showed five unresolved clades: lanceolata, longipoda, brincki/noodti, hinumaensis/oshimaensis, and muvattupuzha/sultej/irenae/singhalensis. This is without a doubt a result of many unknown characters, as most of these species are only known after a limited set of morphological characters.

The easiest division of the brevipes group based on morphological characters would be according to the presence/absence of the inner distal process on the male fifth leg (Character 35), but our cladistics analysis did not support it. This indicates that the structure was lost independently numerous times. It is today present only in five species (P. brincki, $P$. irenae, P. muvattupuzha, P. palmerae, and $P$. sultej), but there could be no doubt that this is a plesiomorphic character state as it is present in all 
three outgroups (Table 1). This probably serves best to illustrate the amount of homoplasies in this group and the need for molecular tools and alternative morphological characters in reconstructing their phylogeny.

\section{Key to species of the brevipes group of the genus Parastenocaris}

Together with the newly described $P$. koreana, currently20 species can be recognized in the brevipes group, and a key to aid in their difficult determination is given below. It is adopted and augmented from Karanovic (2005a) and based solely on the morphology of males, since females of $P$. brincki, $P$. lanceolata and $P$. singhalensis are still unknown.

1. Caudal rami without unguiform process $\ldots \ldots \ldots \ldots . . . .2$

- Caudal rami with posterior unguiform process ..........

... P. muvattupuzha Ranga Reddy and Defaye, 2009

2. Third leg without endopod …....................... 15

- Third leg with endopod …............................. 3

3. Endopod of third leg reduced to single armature

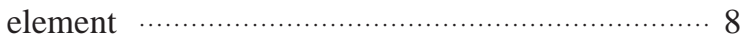

- Endopod of third leg small but distinct segment $\cdots 4$

4. Fourth leg endopod unarmed …..................... 5

- Endopod with bipinnate apical spiniform element .... $P$. jane Karanovic, 2006

5. Fifth leg without inner-distal process $\cdots \ldots \ldots \ldots \ldots \ldots . \ldots$

- Fifth leg with long inner-distal process P. sultej Ranga Reddy, 2011

6. Caudal rami shorter than anal somite, dorsal and lateral setae inserted at midlength $\ldots \ldots \ldots \ldots \ldots \ldots \ldots \ldots \ldots \ldots$

- Caudal rami longer than anal somite, dorsal and lateral setae inserted at $2 / 3$

P. kimberleyensis Karanovic, 2005

7. Third leg exopod with minute outer spine P. feuerborni Chappuis, 1931

- Outer spine much longer, reaching 2/3 of apophysis P. gundlakamma Ranga Reddy, 2011

8. Fifth leg with inner-distal process …................. 9

- Fifth leg without inner-distal process …............ 10

9. Fifth leg armed with only two setae

P. brincki Enckell, 1970

- Fifth leg armed with four setae

P. palmerae Reid, 1991

10. Endopod of fourth leg two-segmented, with two apical spinules 11

- Endopod one-segmented, ornamented with more than

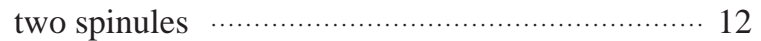

11. Third leg without outer spine on first exopodal segment …............ P. longipoda Shen and Tai, 1973

- This leg with well developed outer exopodal spine ... P. savita Ranga Reddy, 2001

12. First exopodal segment of third leg with large dentate process on inner margin
P. gayatri Ranga Reddy, 2001

- This segment with smooth inner margin ............ 13

13. Endopod of third leg minute spiniform element .. 14

- Endopod of third leg slender seta

P. brevipes Kessler, 1913

14. Anal operculum convex; anal somite 1.6 times as long as caudal rami …................ P. biwae Miura, 1969

- Anal operculum deeply concave; anal somite 1.9 times as long as caudal rami …......... P. koreana sp. nov.

15. Anal operculum smooth …......................... 17

- Anal operculum with row of spinules …........... 16

16. Endopod of fourth leg conical and smooth ................ P. oshimaensis Miura, 1962

- Endopod sickle-shaped, with one long spinule ..........

P. hinumaensis Kikuchi, 1970

17. Fifth leg with inner-distal process

P. irenae Enckell, 1970

- Fifth leg without inner-distal process …........... 18

18. Anal somite with two dorsal rows of spinules …........ P. noodti Enckell, 1970

- Anal somite without ornamentation ….............. 19

19. Endopod of fourth leg with four long spinules .......... P. singhalensis Enckell, 1970

- Endopod smooth, conical, sharply pointed

P. lanceolata Enckell, 1970

\section{ACKNOWLedgements}

Ms Renate Walter (Zoologisches Museum Hamburg, Germany) is kindly acknowledged for the help in preparation of the SEM photographs. Financial support to the senior author came from Brain Pool and NIBR (National Institute of Biological Resources) grants (both in Korea), while the necessary facilities were provided by the Zoologisches Museum in Hamburg and Hanyang University in Seoul. We both want to thank Dr Joo-Lae Cho (National Institute of Biological Resources, Korea) for providing valuable material of the Korean species. Dr Mark Grygier (Lake Biwa Museum, Japan) is acknowledged for his help in collecting material in Japan.

\section{REFERENCES}

Berera, R. and V. Cottarelli. 2003. Two new species of interstitial harpacticoids from southern Italy and proposal of a new genus Parastenocaris species-group. Italian Journal of Zoology 70:261-268.

Borutzky, E.V. 1952. Harpacticoida Presnikh Vod. Fauna SSSR, Rakoobraznie, 3(4), Akademia Nauk SSSR, Moscow and Leningrad: 1-424 [in Russian].

Boxshall, G.A. and S.H. Halsey. 2004. An Introduction to Copepod Diversity: 1-966 (The Ray Society, London). 
Boxshall, G.A. and D. Jaume. 2000. Making waves: the repeated colonization of freshwater by copepod crustaceans. Advances in Ecological Research 31:61-79.

Chang, C.Y. 2009. Inland-water Copepoda. Illustrated Encyclopedia of Fauna and Flora of Korea 42:1-687 [in Korean].

Chang, C.Y. 2010. Continental Harpacticoida. Invertebrate Fauna of Korea, 21(4), National Institute of Biological Resources, Korea, pp. 1-244.

Chappuis, P.A. 1931. Copepoda Harpacticoida der Deutschen Limnologischen Sunda-Expedition. Archiv für Hydrobiologie, Supplementband 8, Tropische Binnengewässer 1: 512-584.

Chappuis, P.A. 1937. Subterrane Harpacticoiden aus NordSpanien. Bulletin de la Société des Sciences de Cluj, Roumanie 8:556-571.

Corgosinho, P.H.C. and P. Martínez Arbizu. 2005. Two new interstitial species of Remaneicaris Jakobi (Copepoda, Harpacticoida, Parastenocarididae) from the Ribeirão do Ouro River, Brazil, with a redefinition of the genus. Senckenbergiana Biologica 85:147-162.

Corgosinho, P.H.C., P. Martínez Arbízu and E.N. dos SantosSilva. 2007. Three new species of Remaneicaris Jakobi, 1972 (Copepoda, Harpacticoida, Parastenocarididae) from the Ribeirão do Ouro River, Minas Gerais, Brazil, with some remarks on the groundpattern of the Parastenocarididae. Zootaxa 1437:1-28.

Corgosinho, P.H.C., P. Martínez Arbizu and E.N. dos SantosSilva. 2010. Revision of Brasilibathynellocaris Jakobi, 1972 (Copepoda: Harpacticoida: Parastenocarididae) with redefinition of the genus. Zoological Journal of the Linnean Society 159:527-566.

Cottarelli, V., M.C. Bruno and R. Berera. 2006. A new species of Parastenocaris from Mindoro Island, Philippines: Parastenocaris distincta sp. nov. (Crustacea: Copepoda: Harpacticoida: Parastenocarididae). Zootaxa 1368:5768.

Cottarelli, V., M.C. Bruno and R. Berera. 2007. Interstitial harpacticoids from groundwater in Tuscany (Central Italy): Parastenocaris reidae sp. nov., Nitocrella ensifera sp. nov., and notes on the morphology of Parastenocaris cf. glacialis Noodt (Crustacea: Copepoda). Italian Journal of Zoology 74:83-99.

Cottarelli, V., M.C. Bruno and R. Berera. 2008. Two new species of Parastenocaris (Copepoda, Harpacticoida, Parastenocarididae) from groundwater of Sardinia and Sicily. Crustaceana 81:537-555.

Cottarelli, V., M.C. Bruno and R. Berera. 2010. First record of Parastenocarididae from Thailand and description of a new genus (Copepoda: Harpacticoida). Journal of Crustacean Biology 30:478-494.

Culver, D. and T. Pipan. 2009. The biology of caves and other subterranean habitats: 1-256: Oxford University Press, Oxford.
Dussart, B.H. 1979. Algunos copépodos de América del Sur. Publicación Ocasional, Museo Nacional de Historia Natural, Santiago 30:1-13.

Dussart, B. and D. Defaye. 1990. Répertoire mondial des crustacés copépodes des eaux intérieures, III. Harpacticoïdes. Crustaceana supplement 16:1-384(Brill, Leiden).

Enckell, P.H. 1970. Parastenocarididae (Copepoda Harpacticoida) from Ceylon. Arkiv för Zoologi n. ser. 2, 22(13): 545-556.

Frakes, L.A. 1999. Evolution of Australian environments. Flora of Australia (2nd edition) 1:163-203.

Galassi, D.M.P. and P. De Laurentiis. 2004. Towards a revision of the genus Parastenocaris Kessler, 1913: establishment of Simplicaris gen. nov. from groundwaters in central Italy and review of the $P$. brevipes group (Copepoda, Harpacticoida, Parastenocarididae). Zoological Journal of the Linnean Society 140:417-436.

Glatzel, T. and H.K. Schminke. 1996. Mating behaviour of the groundwater copepod Parastenocaris phyllura Kiefer, 1938 (Copepoda: Harpacticoida). Contributions to Zoology 66:103-108.

Goloboff, P. 1999. NONA(NO NAME) Version 2. Tucumán, Argentina: Published by the author.

Humphreys, W.F. 2000. Background and glossary. In: H. Wilkens, D.C. Culver and W.F. Humphreys (eds.), Ecosystems of the World, 30, Subterranean Ecosystems: 314. Elsevier, Amsterdam.

Huys, R. 2009. Unresolved cases of type fixation, synonymy and homonymy in harpacticoid copepod nomenclature (Crustacea: Copepoda). Zootaxa 2183:1-99.

Huys, R. and G.A. Boxshall. 1991. Copepod Evolution. The Ray Society, London. 468 pp.

ICZN. 1999. Fourth edition. The International Trust for Zoological Nomenclature. London.

Jakobi, H. 1969. Forficatocaris noodti n. gen., sp. nov. (Copepoda, Harpacticoidae) aus brasilianischem Limnopsammal. Crustaceana 17:231-238.

Jakobi, H. 1972. Trends (Enp.P4 Mänchen) innerhalb der Parastenocarididen (Copepoda Harpacticoidea). Crustaceana 22:127-146.

Karanovic, T. 2004. Subterranean Copepoda from arid Western Australia. Crustaceana Monographs, 3: i-vi, Brill, Leiden. 366 pp.

Karanovic, T. 2005a. Two new subterranean Parastenocarididae (Crustacea, Copepoda, Harpacticoida) from Western Australia. Records of the Western Australian Museum 22:353-374.

Karanovic, T. 2005b. Two new genera and three new species of subterranean cyclopoids (Crustacea, Copepoda) from New Zealand, with redescription of Goniocyclops silvestris Harding, 1958. Contributions to Zoology 74:223254.

Karanovic, T. 2006. Subterranean Copepods (Crustacea, Copepoda) from the Pilbara Region in Western Australia. 
Records of the Western Australian Museum 70(suppl.): $1-239$.

Karanovic, T. 2008. Marine Interstitial Poecilostomatoida and Cyclopoida (Copepoda) of Australia. Crustaceana Monographs, 9: i-vi, Brill, Leiden. 331 pp.

Karanovic, T. and M. Bobic. 1998. Two new species of Copepoda Harpacticoida from east Serbia (Balkan Peninsula): Parastenocaris serbica sp. n. and Bryocamptus (R.) borus sp.n. Crustaceana 71: 171-184.

Karanovic, T. and M. Krajicek. 2012. When anthropogenic translocation meets cryptic speciation globalized bouillon originates; Molecular diversity of the cosmopolitan freshwater cyclopoid Macrocyclops albidus (Crustacea: Copepoda). International Journal of Limnology 48(1) (in press).

Karanovic, T. and P. Hancock. 2009. On the diagnostic characters of the genus Stygonitocrella (Copepoda, Harpacticoida), with descriptions of seven new species from Australian subterranean waters. Zootaxa 2324:1-85.

Karanovic, T. and S.J.B. Cooper. 2011a. Molecular and morphological evidence for short range endemism in the Kinnecaris solitaria complex (Copepoda: Parastenocarididae), with descriptions of seven new species. Zootaxa 3026:1-64.

Karanovic, T. and S.J.B. Cooper. 2011b. Third genus of parastenocaridid copepods from Australia supported by molecular evidence (Harpacticoida: Parastenocarididae). Leiden: Brill, Crustaceana Monographs 16:293-337.

Karanovic, T. and Y. Abe. 2010. First record of the harpacticoid genus Morariopsis (Crustacea: Copepoda: Canthocamptidae) in Japan, and its zoogeographic implications. Species Diversity 15:185-208.

Karanovic, T. and Y. Ranga Reddy. 2004. First record of Phyllognathopus bassoti Rouch, 1972 from India, with remarks on the family Phyllognathopodidae Gurney, 1932 (Crustacea, Copepoda, Harpacticoida). International Journal of Limnology 40:121-132.

Karanovic, T. and Y. Ranga Reddy. 2005. First Haplocyclops Kiefer (Crustacea, Copepoda) from Indian subterranean waters: the most reduced free-living cyclopoid. International Journal of Limnology 41:83-92.

Karanovic, T., J.-L. Cho and W. Lee. 2012. Redefinition of the parastenocaridid genus Proserpinicaris (Copepoda: Harpacticoida), with description of three new species from Korea. Journal of Natural History (in press).

Kessler, E. 1913a. Parastenocaris brevipes nov. gen. et nov. spec., ein neuer Süsswasser-Harpacticide. Zoologischer Anzeiger 42:514-520.

Kessler, E. 1913b. Zur Kenntnis der Harpacticidengattung Parastenocaris mihi. Zoologischer Anzeiger 43:250-254.

Kiefer, F. 1976. Ruderfusskrebse (Crustacea, Copepoda) aus dem Sandlückensystem einiger Bäche der Ostalpen. Beiträge zur Naturkundlichen Forschung in Südwestdeutschland 35:111-118.

Kikuchi, Y. 1970. A new species of Parastenocaris (Harpac- ticoida) from a sandy beach of the Lake Hinuma. Annotationes Zoologicae Japonenses 43:170-173.

Kunz, H. 1938. Harpacticoiden vom Sandstrand der Kurischen Nehrung. Studien an marinen Copepoden, III. Kieler Meeresforschungen 3:148-157.

Lang, K. 1948. Monographie der Harpacticiden. NordiskaBokhandeln, Stockholm, 2 volumes, pp. 1-1682.

Lee, J.M. and C.Y. Chang. 2009. Two groundwater copepods of the genus Parastenocaris (Harpacticoida, Parastenocarididae) from South Korea. Animal Cells and Systems 13:169-178.

Martínez Arbizu, P. and G. Moura. 1994. The phylogenetic position of the Cylindropsyllinae Sars (Copepoda, Harpacticoida) and the systematic status of the Leptopontiinae Lang. Zoologische Beiträge 35:55-77.

Miura, Y. 1962. Subterranean harpacticoid copepods of the Amami Group of the Ryukyu Islands. Annotationes Zoologicae Japonenses 35:95-105.

Miura, Y. 1964. Subterranean harpacticoid copepods from a driven well in Japan. Japanese Journal of Zoology 14: 133-141.

Miura, Y. 1969. Results of the speleological survey of South Korea 1966, XIV. Subterranean harpacticoid copepods of South Korea. Bulletin of the National Science Museum, Tokyo, Series A, Zoology 12:241-254.

Nixon, K.C. 2002. WinClada version 1.00.08. Published by the author, Ithaca, New York.

Noodt, W. 1962. Limnisch-subterrane Copepoden der Gattung Parastenocaris Kessler aus Mittelamerika. In: E. Titschack and H.-W. Koepcke (eds.), Beiträge zur neotropischen Fauna 2: 223-248 (VEB Gustav Fischer Verlag, Jena).

Noodt, W. 1963. Subterrane Crustaceen der zentralen Neotropis. Zoologischer Anzeiger 171:114-147.

Noodt, W. 1972. Drei neue Parastenocaris aus Kolumbien (Crustacea Copepoda), 1. Mitteilung über kolumbianische Grundwasser-Crustaceen. Studies on Neotropical Fauna 7:101-112.

Playford, P. 2003. The Permo-Carboniferous glaciations of Gondwana: its impact on Western Australia. Western Wildlife 7:1-5.

Por, F.D. and V.F. Hadel. 1986. Two new species of Attheyella (Copepoda: Harpacticoida: Canthocamptidae) from bromeliads of the Serra da Juréia (São Paulo, Brazil). Journal of Crustacean Biology 6:777-788.

Ranga Reddy, Y. 2001. Discovery of Parastenocarididae (Copepoda, Harpacticoida) in India, with the description of three new species of Parastenocaris Kessler, 1913, from the River Krishna at Vijayawada. Crustaceana 74: 705-733.

Ranga Reddy, Y. 2011. Two new hyporheic Parastenocarididae from India: Parastenocaris sutlej n. sp. and P. gundlakamma n. sp. (Copepoda, Harpacticoida). Leiden: Brill, Crustaceana Monographs 16:461-487. 
Ranga Reddy, Y. and D. Defaye. 2007. Parastenocarididae (Crustacea, Copepoda, Harpacticoida) of India: description of Parastenocaris mahanadi sp. nov., and redescription of $P$. curvispinus Enckell, 1970 from hyporheic habitats. Zootaxa 1580:1-26.

Ranga Reddy, Y. and D. Defaye. 2009. Two new Parastenocarididae (Copepoda, Harpacticoida) from India: Parastenocaris muvattupuzha sp. nov. from a river and P. kotumsarenis sp. nov. from a cave. Zootaxa 2077:31-55.

Reid, J.W. 1991. Diacyclops albus sp. nov. and Parastenocaris palmerae sp. nov. (Crustacea: Copepoda) from the meiofauna of a stream bed in Virginia, U.S.A. Canadian Journal of Zoology 69:2893-2902.

Reid, J.W. 1994. Murunducaris juneae, new genus, new species (Copepoda: Harpacticoida: Parastenocarididae) from a wet campo in central Brazil. Journal of Crustacean Biology 14:771-781.

Reid, J.W. 1995. Redescription of Parastenocaris brevipes Kessler and description of a new species of Parastenocaris (Copepoda: Harpacticoida: Parastenocarididae) from the U.S.A. Canadian Journal of Zoology 73:173-187.

Reid, J.W. 2001. A human challenge: discovering and understanding continental copepod habitats. Hydrobiologia 453/454:201-226.

Sanmartin, I. and F. Ronquist. 2004. Southern Hemisphere biogeography inferred by event-based models: plant versus animal patterns. Systematic Biology 53:216-243.

Schminke, H.K. 1976. Systematische Untersuchungen an Grundwasserkrebsen eine Bestandsaufnahme (mit der Beschreibung zweier neuer Gattungen der Familie Parabathynellidae, Bathynellacea). International Journal of
Speleology 8:195-216.

Schminke, H.K. 2008. First record of groundwater fauna from Papua New Guinea: Kinnecaris Jakobi, 1971 redefined (Copepoda, Harpacticoida, Parastenocarididae), and description of a new species. Crustaceana 81:1241-1253.

Schminke, H.K. 2009. Monodicaris gen. n. (Copepoda, Harpacticoida, Parastenocarididae) from West Africa. Crustaceana 82:367-378.

Schminke, H.K. 2010. High-level phylogenetic relationships within Parastenocarididae (Copepoda, Harpacticoida). Crustaceana 83:343-367.

Shen, C.J. and A.Y. Tai. 1973. Preliminary analysis of the characteristics of the harpacticoid Copepoda fauna of China and description of some new species. Acta Zoologica Sinica 19:365-384.

Stock, J.K. and J.C. von Vaupel Klein. 1996. Mounting media revisited: the suitability of Reyne's fluid for small crustaceans. Crustaceana 69:749-798.

Waters, J.M. and D. Craw. 2006. Goodbye Gondwana? New Zealand biogeography, geology, and the problem of circularity. Systematic Biology 55:351-356.

Waters, J.M. and M.S. Roy. 2004. Out of Africa: The slow train to Australasia. Systematic Biology 53:18-24.

Wells, J.B.J. 2007. An annotated checklist and keys to the species of Copepoda Harpacticoida. Zootaxa 1568:1-872.

Wilson, G.D.F. 1999. Some of the deep-sea fauna is ancient. Crustaceana 72:1019-1029.

Submitted: January 31, 2012, Accepted: February 9, 2012 